\title{
R\&D and Technology Spillovers via FDI: Innovation and Absorptive Capacity
}

\author{
By: Yuko Kinoshita
}

Working Paper Number 349

November 2000 


\title{
$R \& D$ and technology spillovers via FDI: Innovation and absorptive capacity
}

\author{
Yuko Kinoshita * \\ CERGE-EI, CEPR and $\mathrm{WDI}^{\dagger}$
}

November 2000

\begin{abstract}
A bstract
Two faces of R\&D (innovation and learning) and technology spillovers from FDI (foreign direct investment) on a firm's productivity growth are examined in this paper.

Using firm-level panel data on Czech manufacturing firms between 1995 and 1998, I find that:

(i) the learning effect of $R \& D$ is far more important than the innovative effect in explaining the productivity growth of a firm,

(ii) there is no evidence of technology spillovers to local firms from having a foreign joint venture partner,

(iii) positive spillovers from FDI are found in electrical machinery and radio\&TV sectors, which are also active investors in innovative R\&D.
\end{abstract}

\footnotetext{
*Correspondence: yuko.kinoshita@cerge.cuni.cz. I thank Jan Kmenta, Jan Svejnar, Bernard Yeung, Kresimir Zigic and participants at CEPR/WDI Annual Conference on Transition Economies in Moscow for comments and Murali Parsa at the Czech Statistical Office for providing the data.

${ }^{\dagger}$ William Davidson Institute, University of Michigan Business School
} 


\section{Introduction}

The accumulation of knowledge is one of the key determinants for the economic growth of a country. The stock of knowledge or technology can be increased by deliberate investment in R\&D capital or by the diffusion of existing technology. Innovations generated by R\&D activities and technology spillovers from the stock of knowledge are both important in enhancing firms' productivity as well as being closely related to each other.

This paper studies the effects of both R\&D investment and technology spillovers from foreign direct investment (FDI) on a firm's productivity growth. I pay special attention to "the two faces of R\&D" - innovation and 'absorptive' or 'learning' capacity - as Cohen and Levinthal (1989) propose. That is, R\&D not only stimulates innovation but also develops the firm's ability to identify, assimilate, and exploit outside knowledge. This second role of $\mathrm{R} \& \mathrm{D}$ is considered to be very important particularly for assessing the extent of technology spillovers from others. Technology diffusion is not an automatic consequence from the presence of others' knowledge stock. It also requires that the recipient possesses the ability to absorb and adopt the technology and that R\&D activities will help increase the incidence of technology spillovers by enhancing the firm's absorptive capacity.

In this study, R\&D affects the productivity growth of firms via two channels. First, it directly increases the technology level by adding more new information (innovation). Second, R\&D increases the absorptive capacity of the firm and induces a greater extent of technology spillovers indirectly. The empirical set-up for this study is drawn from Griffith, Redding, and Van Reenen (2000). They examine the two roles of R\&D in explaining the productivity convergence of 13 OECD countries at the industry level. They find innovative and absorptive R\&D equally important.

The other branch of the literature I draw upon is technology spillovers though FDI. Among many channels of technology diffusion ${ }^{1}$, FDI is one of the most important vehicles ${ }^{2}$ because FDI can transfer technology embodied

\footnotetext{
${ }^{1}$ International trade is another important avenue for international technology diffusion. [Grossman and Helpman (1991), Coe and Helpman (1995), and Keller (1997)] Technology is also transmitted via reading and exchanging scientific journals or commercially obtained by licensing agreements. [Eaton and Kortum (1996)]

${ }^{2}$ There are four channels through which technology spills over from foreign to local firms: (1) demonstration-imitation effects, (2) competition effects, (3) foreign link-
} 
in human capital which would not be transferred otherwise ${ }^{3}$. Also in the theoretical literature of technology transfer from foreign to domestic firms, Wang and Blomstrom (1992) point to the importance of the learning efforts or the absorptive capacity of host country firms in increasing the rate of technology transfer.

In the empirical studies of technology diffusion via FDI, the evidence is rather mixed despite its premise of potential gains from FDI particularly at the firm- and plant-levels. For example, Haddad and Harrison (1993) and Blomstrom and Sjoholm (1999) find no evidence of technology spillovers at both firm and industry level for Moroccan and Indonesian manufacturing firms, respectively. Djankov and Hoekman (1998) report similar results for Czech manufacturing and non-manufacturing firms. In the Venezuelan manufacturing sector, however, Aitken and Harrison (1999) show that there are benefits of foreign investment but they are captured by foreign joint ventures but not by foreign presence in the industry. These contradictory findings suggest that the incidence of technology spillovers may be dependent on the initial level of technology of local firms relative to that of foreign firms. Kokko (1994) confirms this point from his results on Mexican manufacturing firms by stating that the incidence of technology spillovers are conditional on the technology level of local firms relative to that of foreign firms.

In this study, I explicitly introduce $R \& D$ investment as a part of the learning efforts by the host country firm. The empirical set-up in this study is manufacturing firms operating in the Czech Republic between 1995 and 1998. Total factor productivity (TFP) growth of these firms is determined by three factors: R\&D, FDI, and the firm's absorptive capacity. I find that: (i) the learning effect of $R \& D$ is far more important than the innovative effect in explaining the productivity growth of a firm; (ii) there is no evidence of technology spillovers from having a foreign joint venture partner to local firms; and (iii) positive spillovers from FDI are found in electrical machinery and radio\&TV sectors, which are also active investors in innovative $R \& D$.

This paper is organized as follows. In the next section, empirical specifications are discussed in light of the theoretical literature. In section 3, the data and summary statistics are described and regression results are examined in

age effects, and (4) training effects. See Kokko (1992) and Kinoshita (1999) for further discussion.

${ }^{3}$ Mansfield (1980) reports that FDI conveys newer technology than trade. 
section 4 . Finally, section 5 concludes my findings.

\section{Framework}

\subsection{R\&D and productivity growth}

Suppose the production function of firm $i$ is expressed as:

$$
Y_{i t}=A_{i t} L_{i t}^{\alpha} K_{i t}^{1-\alpha}
$$

where $Y_{i t}$ is value-added, $A_{i t}$ is total factor productivity (TFP) or Solow residual, $L_{i t}$ is labor input, and $K_{i t}$ is physical capital stock. $A_{i t}$ is related to R\&D capital stock as follows:

$$
A_{i t}=B_{i t} R_{i t}^{\rho}
$$

where $R_{i t}$ is the stock of $\mathrm{R} \& \mathrm{D}$ capital and $B_{i t}$ is other factors that influence TFP. $R_{i t}$ can be considered as a firm's intangible assets and thus it is unobservable. It is accumulated over time by investments in knowledge and technology.

Time-differentiating equation (2), I get:

$$
\frac{\triangle A_{i t}}{A_{i t}}=\frac{\triangle B_{i t}}{B_{i t}}+\rho \frac{\triangle R_{i t}}{R_{i t}}
$$

where $\rho$ is the elasticity of value-added with respect to R\&D capital stock. In order to estimate the series of R\&D capital stock directly, I need additional assumptions. Following Griliches (1980), Nadiri (1980), and Goto and Suzuki (1989), the evolution of R\&D capital stock over time can be described as follows (the $i$ th subscript is dropped):

$$
R_{t}={ }_{k=1}^{\chi^{n}} \mu_{k} E_{t-k}+(1-\delta) R_{t-1}
$$

That is, $R \& D$ capital stock at time $t$ is the sum of all past $R \& D$ expenditures $\left\{E_{t-k}\right\}$ and depreciated R\&D capital at time t- 1 where $\mu_{k}$ is a distributed lag and $\delta$ is a rate of obsolescence of $\mathrm{R} \& \mathrm{D}$ capital. For the first term in (4), I need to specify the lag structure. (e.g. R\&D expenditures in time t- $\tau$ 
constitute the increase in $R \& D$ capital at time t.) In the literature, people often use the average lag $\tau$ and $\mu_{k}=1$ if $k=\tau$ and $\mu_{k}=0$ if $k \neq \tau$. (4) then becomes:

$$
R_{t}=E_{t-\tau}+(1-\delta) R_{t-1}
$$

The rate of obsolescence of $\mathrm{R} \& \mathrm{D}$ capital, $\delta$, is somewhat similar to the rate of depreciation of physical capital. The main difference is, however, that R\&D capital also depreciates as knowledge diffuses to people other than the innovator. The estimation of $\delta$ requires some information on patent renewal data. ${ }^{4}$ In the absence of patent renewal data, it is not possible to estimate a series of R\&D capital stock directly. One way to derive the rate of return on $R \& D$ investment without estimating the rate of obsolescence is to assume that $\delta$ is small enough. If $\delta$ is computed as an inverse of the length of time a patent generates royalty revenue as in Goto and Suzuki (1989), then I am implicitly assuming that the average life span of patents is long enough. ${ }^{5}$ The other conventional way to avoid the estimation of the rate of obsolescence is to set $\delta$ to a plausible level, say, $10 \%$ as some researchers do. In this paper, I choose the first approach to compute the rate of return to R\&D capital. ${ }^{6}$

Assuming that $\delta$ is small and that the average lag is one year $(\tau=1)$ in (5), I get:

$$
\frac{\triangle R_{t}}{R_{t}}=\frac{E_{t}}{R_{t}}
$$

The substitution of (6) into (3) yields:

$$
\frac{\triangle A_{i t}}{A_{i t}}=\frac{\triangle B_{i t}}{B_{i t}}+\eta \frac{E_{i t}}{Y_{i t}}
$$

where $\eta$ is marginal product of $\mathrm{R} \& \mathrm{D}$ or the rate of return on $\mathrm{R} \& \mathrm{D}$ investment. $^{7}$

\footnotetext{
${ }^{4}$ One can compute the net profit of a patent as a discounted sum of the revenue from a patent (royalty) minus the patent renewal fee. See Bosworth (1978), Pakes and Shankerman (1984), and Goto and Suzuki (1989) for more details.

${ }^{5}$ This is true for industries that are not so technology-intensive.

${ }^{6}$ Griliches and Mairesse (1984) and Griffith, Redding, and van Reenen (2000) use this approach as well. Hall and Mairesse (1995) report that the choice of depreciation rate for R\&D capital makes little difference to $R \& D$ elasticity estimates in the study of French manufacturing firms.

${ }^{7} \rho=\frac{\partial Y}{\partial R} \cdot \frac{R}{Y}$ by definition and $\rho \frac{\Delta R}{R}=\frac{\partial Y}{\partial R} \cdot \frac{R}{Y} \cdot \frac{E}{R}=\eta \frac{E}{Y}$.
} 


\subsection{Technology spillovers from FDI and productivity growth}

Another focus of this analysis is FDI as an engine of the productivity growth of a firm. Foreign investment can be considered here as the inflow of advanced knowledge from foreign firms. In particular, among many channels through which foreign knowledge spills over to a country, FDI is one of the most effective forms of international technology transfer because FDI can convey not only technology embodied in goods and services but also intangible assets such as managerial skills that would not be transferred through other avenues.

At the firm level, local firms in the host country can benefit from FDI via roughly four channels. ${ }^{8}$ First, foreign technology embodied in FDI can be transferred from foreign to local firms as local firms imitate what foreign firms do. Firms invest abroad in order to exploit firm-specific capabilities and they are thus typically characterized as efficient firms that possess intangible assets. Second, the productivity growth of local firms may be affected by competitive pressures due to the entry of efficient foreign firms. Third, by purchasing intermediate inputs from foreign suppliers or by selling output to foreign producers of final goods, local firms may be able to produce output with a higher standard or be forced to use more efficient technology, respectively. Finally, foreign firms may engage in training workers in local firms especially when they are joint venture partners.

It is, however, difficult to distinguish one from the other since the mechanism of technology spillovers from FDI is complex and often interdependent. Nevertheless, within the limitation of available data, I use two variables that reflect the degree of technology spillovers through FDI in the current empirical set-up.

The first variable is the foreign ownership dummy FORGN $N_{i t}$ at time t. The past studies often use this variable as a proxy for intra-firm technology spillovers from FDI. FORGN $N_{i t}$ is 1 if shares owned by foreign firms are equal to or greater than $50 \%$ and 0 otherwise. ${ }^{9}$ According to this classification,

\footnotetext{
${ }^{8}$ See Kokko (1992) and Kinoshita (1999) for further discussion.

${ }^{9}$ The cut-off level of foreign shares used in many studies at the firm level is usually $5 \%$ or $10 \%$. This definition of $50 \%$ or greater is given by the Czech Statistical Office in the question on ownership structure. The effect of foreign ownership on productivity growth may be underestimated due to the difference in definitions of foreign ownership in comparison with the existing studies.
} 
I define only firms with foreign majority shares as foreign-owned firms (e.g. firms with $F O R G N_{i t}=1$ ).

The second variable is $F O R_{j(i) t}$, which proxies foreign presence in the sector measured as the share of employment by foreign-owned firms to total employment within the industry. Namely, $F O R_{j(i) t}$ denotes sectoral foreign stock at time $t$ in the $j$ th industry to which the $i$ th firm belongs. This variable is considered to reflect the degree of intra-industry technology spillovers from FDI.

These two variables are incorporated into $\frac{\Delta B_{\mathrm{it}}}{B_{\mathrm{it}}}$.

$$
\frac{\triangle B_{i t}}{B_{i t}}=\mu_{1} F O R G N_{i t}+\mu_{2} F O R_{j(i) t}+d_{j}+d_{t}
$$

where $d_{j}$ is a sectoral dummy and $d_{t}$ is a year dummy to control for crosssectional and time-series differences. Substituting (8) into (7), I get:

$$
\frac{\triangle A_{i t}}{A_{i t}}=\eta \frac{E_{i t}}{Y_{i t}}+\mu_{1} F O R G N_{i t}+\mu_{2} F O R_{j(i) t}+d_{j}+d_{t}
$$

$\eta, \mu_{1}$, and $\mu_{2}$ are expected to be positive and significant if they raise a firm's productivity. Alternatively, I can also run the following regression to get the estimates for the variables of our interest:

$$
\begin{aligned}
\frac{\triangle Y_{i t}}{Y_{i t}}= & \alpha_{0}+\alpha \frac{\triangle L_{i t}}{L_{i t}}+(1-\alpha) \frac{\triangle K_{i t}}{K_{i t}}+\eta \frac{E_{i t}}{Y_{i t}} \\
& +\mu_{1} F O R G N_{i t}+\mu_{2} F O R_{j(i) t}+d_{j}+d_{t}+\varepsilon_{i t}
\end{aligned}
$$

It should be noted that this is closely related to the specification that Haddad and Harrison (1993) and Aitkin and Harrison (1999) use in their studies of manufacturing firms in Morocco and Venezuela, respectively. The novelty of this model is that I include R\&D investment in the effort level of local firms to increase the stock of knowledge.

$\mathrm{R} \& \mathrm{D}$ is directly related to TFP growth in the above specification. $\mathrm{R} \& \mathrm{D}$ may also affect the extent of technology spillovers from FDI by increasing a firm's capacity to absorb new technology more effectively. Griffith, Redding, and Van Reenen (2000) distinguish the two faces of R\&D - innovation and enhancement of absorptive capacity - and analyze both roles of R\&D empirically on productivity growth of industries in OECD countries. They indeed 
find evidence that R\&D not only stimulates innovation but also facilitates the imitation of others' discoveries.

The current study also addresses this issue by relating $R \& D$ to the size of technology spillovers. That is, the $R \& D$ variable affects via two channels. One is through a direct channel $(\eta)$ and the other is through the absorptive capacity $\left(\mu_{1}\right.$ and $\left.\mu_{2}\right) .{ }^{10}$ Equation (10) is extended into the following form:

$$
\begin{aligned}
\frac{\triangle Y_{i t}}{Y_{i t}}= & \alpha_{0}+\alpha \frac{\triangle L_{i t}}{L_{i t}}+(1-\alpha) \frac{\triangle K_{i t}}{K_{i t}}+\eta \frac{E_{i t}}{Y_{i t}}+\mu_{1} F O R G N_{i t}+\mu_{2} F O R_{j(i) t} \\
& +\mu_{3}\left(\frac{E_{i t}}{Y_{i t}}\right) F O R G N_{i t}+\mu_{4}\left(\frac{E_{i t}}{Y_{i t}}\right) F O R_{j(i) t}+d_{j}+d_{t}+\varepsilon_{i t}
\end{aligned}
$$

\section{Data}

Two data sets are used for this study. Both data sets are collected by the Czech Statistical Office. The first data set is the quarterly data that was compiled from firms' balance sheets and income statements from the first quarter of 1993 through the last quarter of 1998. Most of the variables necessary for the estimation were drawn from this data set.

The second data set is the annual survey on R\&D and licenses. Since R\&D expenditures are reported by firms annually from 1995 through 1998, the quarterly firm-level data was merged into the annual level and then the two data sets were merged according to the firm identifier and year. Finally, the panel data for 1995-1998 has 1217 observations. ${ }^{11}$

Table 1 shows the annual average of two key variables, R\&D propensity and foreign presence, for each sector. R\&D propensity is defined as a ratio of $\mathrm{R} \& \mathrm{D}$ expenditure to value-added and foreign presence is measured as a ratio of employment by foreign-owned firms to total employment in the sector.

Foreign presence varies greatly across sectors. Three sectors that attract much FDI are motor vehicle, rubber, and electrical machinery ${ }^{12}$. Basic metal

\footnotetext{
${ }^{10}$ Note that the degree of technology spillovers in Griffith, Redding and Van Reenen (2000) is defined as the distance from technology frontier or the catch-up effect to the leading-edge technology. Kinoshita (1999) uses the initial difference in technlogy level as the degree of technology transfer.

${ }^{11}$ Computing TFP growth rates, the number of observations drops to 704 .

${ }^{12}$ Notable examples include Volkswagen (German) in motor vehicle, Continental (Ger-
} 
and other transport equipment receive the least FDI in our sample firms. R\&D propensity also varies but to a lesser degree. Other transport equipment, radio\&TV, and motor vehicle exhibit higher R\&D propensity than other sectors.

Note that there is no clear correlation between R\&D propensity and foreign presence. If $R \& D$ propensity implies a level of technological complexity in the sector, then FDI in the Czech Republic is not necessarily going into low-tech sectors with low R\&D intensity. Motor vehicle is an exception since it is relatively more $R \& D$ intensive and receives a lot of FDI as well.

\subsection{Comparisons between foreign and local firms}

A premise of this study is that foreign firms are more technologically advanced than local firms. As technology spills over from foreign to local firms, local firms adopt the new methods of production or management resulting in higher productivity.

The first two columns in table 2 report the average TFP levels computed for each sector and ownership classification (local and foreign firms). In many sectors, I observe higher productivity levels for foreign firms. The exceptions are textile, chemical, machinery, medical equipment, and other transport equipment. As table 1 indicates, textile, machinery, and other transport equipment have very little foreign presence and the average of foreign firms may not be treated as representative due to too few observations. However, foreign presence is large enough and accounts for $11 \%$ in both chemical and medical equipment sectors. In these two sectors, foreign firms are relatively less efficient than local firms. This finding goes against the premise of the superiority of foreign technology. One explanation for this is that local firms had already caught up in technology and surpassed foreign firms prior to 1995.

The last column in table 2 shows the differences by sector between the average TFP growth rates for foreign firms and that for local firms. Positive numbers imply that foreign firms grew faster than local counterparts on average. Negative numbers imply that local firms grew faster than foreign

man) in rubber\& plastic, and Matsushita (Japanese) and Siemens (German) in electrical machinery. 
Table 1: Annual average of R\&D to value-added and foreign employment share by sector (1995-1998)

R\&D / Y Foreign employment share

\begin{tabular}{lll}
\hline \hline & & \\
food & 0.10 & 0.20 \\
textile & 0.03 & 0.05 \\
wood \& paper & 0.06 & 0.10 \\
chemical & 0.13 & 0.11 \\
rubber \& plastic & 0.15 & 0.31 \\
non-metallic mineral & 0.19 & 0.21 \\
basic metal & 0.05 & 0.02 \\
fabricated metal & 0.08 & 0.13 \\
machinery & 0.20 & 0.05 \\
electrical machinery & 0.10 & 0.29 \\
radio\&TV & 0.37 & 0.23 \\
medical equipment & 0.15 & 0.11 \\
motor vehicle & 0.22 & 0.46 \\
other transport equipment & 0.38 & 0.02 \\
other manufacturing & 0.06 & 0.11 \\
ALL & 0.16 & 0.14 \\
& & \\
\hline \hline
\end{tabular}


firms on average. There is no observation for foreign firms in some sectors and in these sectors the TFP growth difference is not available.

The picture here looks different from what I saw in TFP level comparisons. Foreign firms do not necessarily grow faster than local firms on average. Combining the information on growth rate with the information on productivity levels, there are four categories in which I can classify sectors.

In the first group ( food, non-metallic mineral, and other manufacturing), foreign firms are more productive and also continue to grow faster than local firms. In the second group (electrical machinery and radio\&TV), foreign firms are more productive but local firms are catching up with them. On the contrary, in the third group (textile), local firms are more productive but foreign firms are catching up. Finally, in the last group (chemical, machinery, medical equipment, and other transport equipment), local firms are more productive and grow faster than foreign counterparts. For the remaining sectors, there is no difference in TFP growth between foreign and local firms, or, the figure is not available due to lack of foreign observations. I will not discuss these non-grouped sectors here.

The most interesting case is the second group. In electrical machinery and radio\&TV, the superiority of foreign technology is observed and so is the presence of technological catch-up by local firms. There seem to be indeed some positive productive spillovers to local firms from FDI in this case. On the other hand, in the first group (food, non-metallic mineral, and other manufacturing), local firms failed to benefit from the presence of foreign advanced technology. Finally, in the last two groups, the absence of the technological superiority of foreign firms is simply interpreted as a lack of enough information due to little foreign presence in these sectors.

In the next section, I attempt to examine various factors that made a difference between domestic firms in the first and second groups in whether or not they caught up with foreign firms. 
Table 2: Average TFP levels and TFP growth differences by sector and ownership(1995-1998)

TFP level

TFP growth difference

Local firms Foreign firms

\begin{tabular}{lccc}
\hline \hline & & & \\
food & 0 & 0.30 & 0.04 \\
textile & -0.03 & -0.17 & 0.03 \\
wood \& paper & 0.02 & 0.36 & - \\
chemical & 0.16 & 0.05 & -0.03 \\
rubber \& plastic & -0.12 & 0.34 & 0 \\
non-metallic mineral & 0.12 & 0.38 & 0.02 \\
basic metal & 0.07 & 0.76 & - \\
fabricated metal & 0.04 & 0.34 & -0.01 \\
machinery & -0.10 & -0.11 & -0.01 \\
electrical machinery & 0.07 & 0.22 & -0.04 \\
radio\&TV & -0.12 & 1.06 & -0.09 \\
medical equipment & -0.05 & -0.36 & 0 \\
motor vehicle & -0.17 & 0.40 & -0.17 \\
other transport equipment & -0.01 & -1.70 & 0.02 \\
other manufacturing & -0.04 & 0.22 & 0 \\
ALL & -0.02 & 0.19 & \\
& & & \\
\hline \hline
\end{tabular}

Notes:

(1) $T F P$ level $=\ln V A-\alpha_{k} \ln K-\alpha_{l} \ln L$.

(2) $T F P$ growth difference $=(\text { average } T F P \text { growth rate })_{\text {foreign }}-(\text { average } T F P \text { growth rate })_{\text {domestic }}$. 


\section{Estimation Results}

Table 3 presents the results of OLS regressions with innovative R\&D and two foreign variables. The dependent variable is $\ln \frac{Y_{i t}}{Y_{i t-1}}$. The coefficient of R\&D measures the a direct impact of $R \& D$ investment on productivity growth and I call it here innovative $R \& D$ as opposed to absorptive $R \& D$. The coefficient of $R \& D$ is also the rate of return to $R \& D$ investment. All regressions include the intercept and the changes of capital and labor.

FORGN and FOR are the variables that represent spillovers within the firm and within the industry, respectively. FORGN is a foreign ownership dummy and, if foreign joint venture has any effect on productivity growth, I would expect it to be positive. This variable reflects the demonstration effect and possibly includes the linkage and training effects of technology spillovers from FDI. ${ }^{13} \mathrm{FOR}$ is a proxy for foreign presence in the industry measured as the employment share of foreign firms to that of all firms in the industry and mainly reflects demonstration and competition effects.

Column I reports the result without sector dummies. The rate of return to R\&D investment is 0.031 at $1 \%$ level of significance. This implies that one more unit of $R \& D$, in this case, one more $C Z K$ spent on $R \& D$ will lead to an increase of output by $3.1 \%$. Thus, R\&D investment indeed contributes to the generation of new knowledge but the rate of return is lower than that in the studies done in other countries. ${ }^{14}$ The significance of $R \& D$ remains robust throughout regressions in table 1 after including sector and time dummies.

The results for foreign variables are somewhat disappointing. FORGN carries a negative sign throughout regressions, although not statistically significant. The effect of FOR is positive as I expected. But the size of the coefficient is lessened as I control for sector and time differences. ${ }^{15}$

A glance at table 3 indicates that there is no evidence of technology spillovers from FDI once I include the firm's R\&D investment in the model. Since table 1 shows that average foreign firms are not actively engaging in $\mathrm{R} \& \mathrm{D}$ activities, there may be some substitutability between $\mathrm{R} \& \mathrm{D}$ and FORGN.

\footnotetext{
${ }^{13}$ See footnote 2 on page 1.

${ }^{14}$ Goto and Suzuki (1989) report that the rate of return on R\&D for Japanese manufacturing firms is about $30 \%$.

${ }^{15}$ Year dummies are added as proxies for changes of aggregate economic and political environments in column III. However, they are jointly rejected in the model.
} 
Table 3: Innovative R\&D and FDI

\begin{tabular}{lccc} 
& $\mathrm{I}$ & $\mathrm{II}$ & $\mathrm{III}$ \\
\hline \hline $\mathrm{R} \& \mathrm{D} / \mathrm{Y}$ & & & \\
& $.031^{* * *}$ & $.033^{* * *}$ & $.033^{* * *}$ \\
FORGN & $(.007)$ & $(.008)$ & $(.008)$ \\
& -.006 & -.007 & -.007 \\
FOR & $(.007)$ & $(.007)$ & $(.007)$ \\
& .030 & .023 & .026 \\
& $(.019)$ & $(.045)$ & $(.060)$ \\
sector dummies & no & yes & yes \\
time dummies & no & no & yes \\
$N$ & 704 & 704 & 704 \\
adjusted $R^{2}$ & .1709 & .1734 & .1713 \\
& & & \\
\hline \hline
\end{tabular}

Notes:

(1) Dependent variable $=$ Change in $\log$ of value-added.

(2) Intercept, changes in capital and labor are included in regressions but is not reported here.

(3) Parentheses are standard errors. ${ }^{* * * * *}$, and ${ }^{*}$ indicate $1 \%, 5 \%$ and $10 \%$ significance levels, respectively. 
The limited impact of foreign investment is reported by other authors in firm- and plant-level studies. Using two variables similar to FORGN and FOR, Haddad and Harrison (1993) find no positive effects of these variables on productivity growth. Aitken and Harrison (1999) find a positive effect of the foreign joint venture variable but a negative effect of foreign stock in the industry. Kokko (1994) examines the effect of foreign presence within the industry on labor productivity and concludes that technology spillovers are found only in sectors in which technology gaps between foreign and local firms are not too large. More recently, Blomstrom and Sjoholm (1999) draws a similar conclusion and finds that technology spillovers were restricted to non-exporting local firms.

There are a few studies on the effects of FDI in transition countries. Djankov and Hoekman (1998) use the Czech data with coverage of manufacturing and non-manufacturing firms and also find no spillovers from FDI. Rather, imports seem to be the driving force of productivity growth of these firms. Konings (2000) in a study of Poland, Bulgaria, and Romania reports that there are even negative spillovers from FDI in some cases.

All these studies point to the fact that technology spillovers from FDI are not at all automatic consequences from the mere presence of foreign firms. If there are any spillovers present, then they are conditional on some factors endogenous to the recipient firms or industries in the host economy.

Now I introduce "absorptive R\&D" interacted with both foreign spillover variables. In the first column in table 4 , the interaction of $R \& D$ with FORGN is added. Innovative R\&D remains significant and, interestingly enough, R\&D*FORGN shows the negative and significant sign. As I deduced from table 1, R\&D and FORGN are substitutes in explaining productivity growth. In light of absorptive capacity, R\&D does not help increase technology spillovers from foreign ownership but rather decreases the degree of such spillovers.

On the other hand, absorptive $R \& D$ becomes more dominant than innovative $R \& D$ in column II when I add instead the interaction term R\&D*FOR. Thus, R\&D helps increase the degree of intraindustry spillovers from FDI significantly. Innovative R\&D is no longer significant once I account for this type of absorptive capacity. If I define absorptive or learning $R \& D$ as $\mathrm{R} \& \mathrm{D}$ that develops the firm's ability to imitate and exploit outside knowledge, then R\&D*FOR may capture the notion of absorptive capacity more 
appropriately. Since the investor in $R \& D$ is identical to that with foreign ownership, the distinction between $R \& D$ and $R \& D * F O R G N$ is less obvious.

I find in table 4 that the role of $R \& D$ in increasing absorptive capacity is much greater than the conventional role of innovation. Only when the firm performs R\&D actively are there positive spillovers from foreign presence in the industry. Borensztein, De Gregorio, and Lee (1998) in the study of FDI and economic growth draws a conclusion consistent with the current result. In their study, FDI is found to have a positive effect on economic growth only when it is interacted with the level of human capital in the country. The level of human capital is a proxy for absorptive capacity of the recipient country. In the present paper, R\&D is used in place of human capital.

I divide the sample by ownership into local and foreign firms in table 5. The result from table 4 still holds for local firms. Innovative R\&D is outweighed by absorptive $R \& D$ via spillovers from foreign presence in the industry. On the other hand, R\&D plays no important role for productivity growth of foreign firms. Rather, foreign firms increase their productivity from positive externalities from other foreign firms in the same industry. Such positive externalities are recognized when there are sharable inputs within the industry. For example, foreign firms can hire skilled workers already trained by other foreign firms through labor turnover. This also confirms the agglomeration economies of foreign investors in certain sectors such as motor vehicles, electrical machinery, and rubber\&plastic in the Czech Republic. 
Table 4: Innovative and absorptive R\&D and FDI

\begin{tabular}{lccc} 
& I & II & III \\
\hline \hline R\&D/Y & & & \\
& $.036^{* * *}$ & .008 & .010 \\
FORGN & $(.008)$ & $(.011)$ & $(.011)$ \\
& .002 & -.005 & .004 \\
FOR & $(.008)$ & $(.007)$ & $(.008)$ \\
& .025 & -.019 & -.018 \\
$(\mathrm{R} \& D / Y) \times$ FORGN & $-.088^{*}$ & $-.047)$ & $(.047)$ \\
& $(.044)$ & & $-.094^{* *}$ \\
$(\mathrm{R} \& D / Y) \times$ FOR & - & $.233^{* * *}$ & $.240^{* * *}$ \\
& & $(.079)$ & $(.079)$ \\
sector dummies & yes & yes & yes \\
time dummies & no & no & no \\
$N$ & 704 & 704 & 704 \\
adjusted $R^{2}$ & .1768 & .1825 & .1865 \\
& & & \\
\hline \hline
\end{tabular}

Notes:

(1) Dependent variable $=$ Change in $\log$ of value-added.

(2) Intercept, changes in capital and labor are included in regressions but are not reported here.

(3) Parentheses are standard errors. ${ }^{* * *, * *}$ and ${ }^{*}$ indicate $1 \%, 5 \%$ and $10 \%$ significance levels, respectively. 
Table 5: Local and foreign firms

\begin{tabular}{lcc} 
& Local firms & Foreign firms \\
\hline \hline $\mathrm{R} \& \mathrm{D} / \mathrm{Y}$ & & \\
& .007 & .008 \\
$\mathrm{FOR}$ & $(.011)$ & $(.063)$ \\
& -.025 & $.131^{* *}$ \\
$(\mathrm{R} \& \mathrm{D} / \mathrm{Y})^{*} \mathrm{FOR}$ & $.080)$ & $(.064)$ \\
& $(.080)$ & -.256 \\
& & $(.389)$ \\
time dummies & no & no \\
$N$ & 643 & 61 \\
adjusted $R^{2}$ & .1783 & .3084 \\
& & \\
\hline \hline
\end{tabular}

(1) Dependent variable $=$ Change in log of value-added.

(2) Intercept and changes of capital and labor are included in regressions.

(3) Parentheses are standard errors. ${ }^{* *}$ and ${ }^{*}$ indicate $5 \%$ and $10 \%$ significance levels, respectively. 
Table 6: Non-oligopolistic and oligopolistic sectors

\begin{tabular}{lcc} 
& non-oligopolistic sectors & oligopolistic sectors \\
\hline \hline R\&D/Y & & \\
& $-.030^{* *}$ & $.038^{* * *}$ \\
FORGN & $.013)$ & $(.012)$ \\
& -.019 & .006 \\
FOR & $(.012)$ & $(.019)$ \\
& -.044 & $.156^{*}$ \\
sector dummies & $(.068)$ & $(.087)$ \\
time dummies & no & no \\
$N$ & no & no \\
adjusted $R^{2}$ & 84 & 69 \\
& .2367 & .1023 \\
\hline \hline
\end{tabular}

Notes:

(1) Dependent variable $=$ Change in log of value-added.

(2) Intercept and changes of capital and labor are included in regressions.

(3) Parentheses are standard errors. ${ }^{* *}$ and ${ }^{*}$ indicate $5 \%$ and $10 \%$ significance levels, respectively.

(4) Non-oligopolistic sectors=food, non-metallic mineral, others;

Oligopolistic sectors=electrical machinery, radio\&TV.

Sectoral differences introduced as fixed effects are not jointly significant. Nevertheless, the distribution of foreign firms as well as R\&D propensity across sectors is uneven as seen in table 1 . In table 6, I pay special attention to sectors with a relatively large foreign presence. The two groups of sectors I will focus on are based on the observation from table 2. The first group of sectors are those in which foreign firms exhibit higher efficiency, yet local firms fail to catch up with them. Food, non-metallic mineral, and other manufacturing are included in the first group, also called as non-oligopolistic sectors. The second group is oligopolistic sectors which include electrical machinery and radio\&TV. In these sectors, foreign firms show higher productivity and local firms succeed in catching up with them. In both groups, 
there exist foreign firms equipped with superior technology. But what made the difference in the outcome of local firms' productivity?

The answer to this question can be found easily in table 6 . For group 2 in column II, R\&D investment has a substantial contribution to productivity growth. Technology spillovers from foreign stock in the industry are present and the size of the coefficient is large. For group 1, the rate of return to R\&D is even negative and there are naturally no spillovers.

For local firms to narrow the technology gap, foreign presence alone is not enough to guarantee the incidence of technology spillovers. Simultaneous efforts to build up their skill base in the form of R\&D investment is a necessary condition for technology spillovers from FDI in the sector. And electrical machinery and radio\&TV present successful examples. Despite the substantial amount of foreign investment made in the sectors, food, non-metallic mineral and others did not receive spillovers partly because they did not engage in R\&D activities.

This result is consistent with the theoretical predictions made by other authors. The interactions between firms in R\&D activities are often described in a oligopolistic model. Muniagurria and Singh (1997) show that technology spillovers from a more advanced foreign firm to the home firm are realized only when the home firm conducts its own R\&D. In a similar vein, Kamien and Zang (2000) argue that a firm has to enter the $R \& D$ race by engaging in $\mathrm{R} \& \mathrm{D}$, first of all, in order to benefit from spillovers from rival firms in research joint venture. It is natural to assume that these strategic incentives are stronger in an oligopolistic market such as electrical machinery and radio\&TV than food, non-metallic, and others.

\section{Conclusion}

Using unpublished firm-level data on the Czech manufacturing sector between 1995 and 1998, I examined the importance of the firm's R\&D and technology diffusion from FDI in explaining productivity growth. In the analysis, I distinguish the two roles of R\&D: innovation and increasing the absorptive capacity.

The annual rate of return on $R \& D$ investment for pooled samples is estimated as roughly around $3 \%$. Once I include the learning effect of R\&D investment in the model, the direct effect of $\mathrm{R} \& \mathrm{D}$ on productivity growth 
becomes insignificant. Both foreign joint venture (FORGN) and foreign presence in the sector (FOR) are found to have no significant effect on the growth of productivity. But only when FOR is interacted with R\&D does it have a positive and significant effect. This implies that the indirect effect of $R \& D$ via the development of the absorptive capacity is far more important than the direct effect of innovative $R \& D$ in increasing productivity growth of the firm, and that R\&D and intraindustry spillovers from FDI go hand in hand.

The other important finding is that the rate of technology spillovers from FDI varies greatly across sectors. In oligopolistic sectors such as electrical machinery and radio\&TV, there exists a significant rate of spillovers from having a large foreign presence. Also, R\&D investment has a higher rate of return in these sectors. On the other hand, less oligopolistic sectors such as food and non-metallic mineral show no evidence of spillovers despite the large presence of foreign investors in these sectors.

Based on these results, several policy implications can be drawn. First, for the host country to maximize the degree of technology spillovers from FDI, the home country firms should engage in R\&D investment in order to enhance their absorptive capacity. Thus, R\&D subsidies or tax breaks should be accompanied by the promotion of foreign investment. Second, it may be beneficial for the host government to target oligopolistic industries to attract FDI because the benefits of spillovers will be greater provided that domestic industries possess competitiveness in research activities. 


\section{Appendix. Data description}

The first source of the data used in this study is the firm-level survey data drawn from quarterly balance sheets and income statements (6430 observations). The second source is annual R\&D data that consists of 1175 observations. After merging the two by firm identifier and year and counting only those that are in both data sets, the number of observations drops to 995. Excluding those without ownership information and industry classification, it drops further to 919. The combined data contains the information on capital stock, capital investment, number of employees by type, total sales, output, value-added, deflators, ownership classification, and R\&D expenditures.

Firms with foreign ownership are either wholly or partly foreign-owned. The rest of the firms are defined as locally-owned firms. Among local firms, the majority is privately-owned firms. During the period of 1995-1997, there were few changes in ownership classification among sample firms.

According to the 2-digit ISIC, there are 15 sectors: (15) food \& tobacco, (17) textile, apparel \& leather, (20) paper, pulp, wood \& petroleum, (24) chemical, (25) rubber \& plastic, (26) non-metallic mineral, (27) basic metal, (28) fabricated metal, (29) machinery and office machinery, (31) electrical machinery, (32) radio, TV \& communication equipment, (33) medical equipment \& watches, (34) motor vehicle, (35) other transportation equipment, and (36) furniture \& others. Parentheses are the original 2-digit OKEC numbers.

The dependent variable in main regressions is the annual growth rate of value-added. I do not use output, even though it is available, because costs of materials and energy are not available.

The value of fixed assets is reported in company balance sheets. However, due to the revaluation of fixed assets at the beginning of each year, it tends to be overvalued. Instead, I use "depreciated capital" reported in income statements for a proxy of capital stock. ${ }^{16}$ For the labor variable, the number of total employees is used.

\footnotetext{
${ }^{16}$ Djankov and Hoekman(1998) use energy comsuption for capital utilization. However, the figures on energy are not available in the data.
} 


\section{R eferences}

[1] A it ken B. and A. Harrison, "Are there positive spillovers from direct foreign investment?: Evidence from panel data for Morocco." American Economic Review 42 (1999), 51-74.

[2] B en-D avid, D . and M .B . L o ew y, "Free trade and long-run growth." mimemo, University of Houston (1995).

[3] Blomstrom, M. and F. Sjoholm, "Technology transfer and spillovers: Does local participation with multinationals matter? "European Economic Review 43 (1999), 915-923.

[4] B or enszt ein, E., J. De G r egorio, and J . Lee, "How does foreign direct investment affect economic growth?" Journal of International Economics 45 (1998), 115-135.

[5] B o sw orth, D. L., "The rate of obsolescence of technical knowledge: A note. " Journal of Industrial Economics 26 (1978), 273-279.

[6] Caves, R ., Multinational enterprise and economic analysis. Cambridge University Press (1982).

[7] Coe, D. and E. Hel pman, "International R\&D spillovers." European Economic Review (1995), 859-87.

[8] Coe, D., E. Hel pman, and A.H of f maist er, "North-South R\&D spillovers." Economic Journal (1997),134-149.

[9] Cohen, W. and D. Levinthal, "Innovation and learning: The two faces of R\&D." Economic Journal (1989), 569-596.

[10] Djankov, S. and B. Hoekman, "Avenue of technology transfer: foreign investment and productivity change in the Czech Republic." CEPR Discussion Paper No. 1883 (1998). 
[11] Got $0, A$. and K. Suzuki, "R\&D capital, rate of return on R\&D investment and spillovers of R\&D in Japanese manufacturing industries." Review of Economics and Statistics vol.LXXI no.4 (1989), 555-564.

[12] G r if $f$ it h, R. S. R edding, and J. Van Reenen, "Mapping the two faces of R\&D: productivity growth in a panel of OECD industries." IFS Working Paper WP02/00, Institute for Fiscal Studies, London (2000).

[13] Grossman, G. M. and Hel pman, E, Innovation and Growth in the Global Economy. The MIT Press (1991).

[14] Griliches, Z., "R\&D and productivity slowdown." American Economic Review 70 (1980), 343-348.

[15] Griliches, Z. and M air esse, "Productivity and R\&D at the firm level." in REDD, Patents, and Productivity (edited by Z. Griliches), University of Chicago Press (1984).

[16] Haddad, M. and A. Harrison, "Are there positive spillovers from direct foreign investment?: Evidence from panel data for Morocco." Journal of Development Economics 42 (1993), 51-74.

[17] Hal I, B ., "The stock market's valuation of R\&D investment during the 1980's." American Economic Review Papers and Proceedings (1993), 259-264.

[18] H al I, B . and J . M a ir esse, "Exploring the relationship between R\&D and productivity in French manufacturing firms." Journal of Econometrics 65 (1995), 263-293.

[19] K amien, M. and I. Zang, "Meet me halfway: research joint ventures and absorptive capacity." International Journal of Industrial Organization 18 (2000), 995-1012.

[20] K el I er, W ., "Are international R\&D spillovers trade-related? Analyzing spillovers among randomly matched trade partners." European Economic Review (1997), 1469-81.

[21] K inoshit a, Y ., "Technology Spillovers through Foreign Direct Investment." University of Michigan William Davidson Institute Working Paper, No. 221 (1999). 
[22] K okko, A ., Foreign Direct Investment, Host Country Characteristics, and Spillovers. The Economic Research Institute, Stockholm(1992).

[23] K okk 0, A ., "Technology, market characteristics, and spillovers." Journal of Development Economics 43 (1994), 279-293.

[24] K onings, J., "The effects of foreign direct investment on domestic firms: Evidence from firm level panel data in emerging economies." CEPR Discussion Paper No. 2586 (2000).

[25] M ansfield, E. and M. Romeo, "Technology transfer to overseas subsidiaries by U.S.-based firms." Quarterly Journal of Economics 95 (1980), 737-750.

[26] M uniagurria, M. and N. Singh, "Foreign technology, spillovers and R\&D policy." International Economic Review 38 (1997), 405-430.

[27] N a dir i, M . I., "Contributions and developments of research and development expenditures in the U.S. manufacturing industries." in Capital, Efficiency, and Growth (edited by G.M. Furstenburg), Cambridge, MA: Ballinger (1980).

[28] Pakes, A. and M. Schankerman, "The rate of obsolescence of knowledge, research generation lags and private rate of return to research resources." in RED, Patents, and Productivity (edited by Z. Griliches), University of Chicago Press (1984).

[29] Wang, J. and M. B I omst r o m, "Foreign investment and technology transfer: A simple model." European Economic Review 36 (1992), 137155 . 


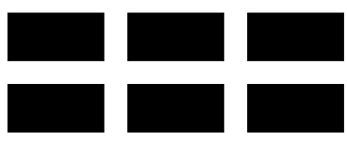

THE WILLIAM DAVIDSON INSTITUTE

AT THE UNIVERSITY OF MICHIGAN BUSINESSSCHOOL

\section{DAVIDSON INSTITUTE WORKING PAPER SERIES}

Working Papers are available at: www.wdi.bus.umich.edu

CURRENT AS OF $11 / 22 / 00$

\begin{tabular}{|c|c|c|}
\hline Publication & Authors & Date \\
\hline $\begin{array}{l}\text { No. } 349 \text { R\&D and Technology Spillovers via FDI: Innovation and } \\
\text { Absorptive Capacity }\end{array}$ & Yuko Kinoshita & Nov. 2000 \\
\hline $\begin{array}{l}\text { No. } 348 \text { Microeconomic aspects of Economic Growth in Eastern } \\
\text { Europe and the Former Soviet Union, } 1950-2000\end{array}$ & Sergei Guriev and Barry W. Ickes & Nov. 2000 \\
\hline $\begin{array}{l}\text { No. } 347 \text { Effective versus Statutory Taxation: Measuring Effective Tax } \\
\text { Administration in Transition Economies }\end{array}$ & $\begin{array}{l}\text { Mark E. Schaffer and Gerard } \\
\text { Turley }\end{array}$ & Nov. 2000 \\
\hline $\begin{array}{l}\text { No. } 346 \text { Objectives and Constraints of Entrepreneurs: Evidence from } \\
\text { Small and Medium Size Enterprises in Russia and Bulgaria }\end{array}$ & $\begin{array}{l}\text { Francesca Pissarides, Miroslav } \\
\text { Singer and Jan Svejnar }\end{array}$ & Oct. 2000 \\
\hline No. 345 Corruption and Anticorruption in the Czech Republic & $\begin{array}{l}\text { Lubomír Lízal and Evžen } \\
\text { Kočenda }\end{array}$ & Oct. 2000 \\
\hline No. 344 The Effects of Direct Foreign Investment on Domestic Firms & Jozef Konings & Oct. 2000 \\
\hline No. 343 On the Identification of Relative Wage Rigidity Dynamics & Patrick A. Puhani & Oct. 2000 \\
\hline $\begin{array}{l}\text { No. } 342 \text { The Determinants of Foreign Direct Investment in Transition } \\
\text { Economies }\end{array}$ & Alan A. Bevan and Saul Estrin & Oct. 2000 \\
\hline No. 341 The Global Spread of Stock Exchanges, 1980-1998 & Klaus Weber and Gerald F. Davis & Nov. 2000 \\
\hline $\begin{array}{l}\text { No. } 340 \text { The Costs and Benefits of Euro-isation in Central-Eastern } \\
\text { Europe Before or Instead of EMU Membership }\end{array}$ & D. Mario Nuti & Oct. 2000 \\
\hline No. 339 Debt Overhang and Barter in Russia & $\begin{array}{l}\text { Sergei Guriev, Igor Makarov and } \\
\text { Mathilde Maurel }\end{array}$ & Sept. 2000 \\
\hline $\begin{array}{l}\text { No. } 338 \text { Firm Performance and the Political Economy of Corporate } \\
\text { Governance: Survey Evidence for Bulgaria, Hungary, Slovakia and } \\
\text { Slovenia }\end{array}$ & $\begin{array}{l}\text { Patrick Paul Walsh and Ciara } \\
\text { Whela }\end{array}$ & July 2000 \\
\hline No. 337 Investment and Instability & $\begin{array}{l}\text { Nauro F. Campos and } \mathrm{J} \\
\text { Nugent }\end{array}$ & May 2000 \\
\hline $\begin{array}{l}\text { No. } 336 \text { The Evolution of the Insurance Sector in Central and } \\
\text { Eastern Europe and the former Soviet Union }\end{array}$ & Robert B.K. Pye & Aug. 2000 \\
\hline $\begin{array}{l}\text { No. } 335 \text { Institutional Technology and the Chains of Trust: Capital } \\
\text { Markets and Privatization in Russia and the Czech Republic }\end{array}$ & Bruce Kogut and Andrew Spicer & Aug. 2000 \\
\hline No. 334 The Evolution of Market Integration in Russia & $\begin{array}{l}\text { Daniel Berkowitz and David N. } \\
\text { DeJong }\end{array}$ & Aug. 2000 \\
\hline No. 333 Efficiency and Market Share in & László Halpern and Gábor Kőrösi & July 2000 \\
\hline No. 332 Search-Money-and-Barter Models of Financial Stabilization & $\begin{array}{l}\text { S.I. Boyarchenko and S.Z. } \\
\text { Levendorskii }\end{array}$ & July 2000 \\
\hline $\begin{array}{l}\text { No. } 331 \text { Worker Training in a Restructuring Economy: Evidence from } \\
\text { the Russian Transition }\end{array}$ & $\begin{array}{l}\text { Mark C. Berger, John S. Earle } \\
\text { and Klara Z. Sabirianova }\end{array}$ & Aug. 2000 \\
\hline $\begin{array}{l}\text { No. } 330 \text { Economic Development in Palanpur 1957-1993: A Sort of } \\
\text { Growth }\end{array}$ & Peter Lanjouw & Aug. 2000 \\
\hline $\begin{array}{l}\text { No. } 329 \text { Trust, Organizational Controls, Knowledge Acquisition from } \\
\text { the Foreign Parents, and Performance in Vietnamese International Joint } \\
\text { Ventures }\end{array}$ & $\begin{array}{l}\text { Marjorie A. Lyles, Le Dang } \\
\text { Doanh, and Jeffrey Q. Barden }\end{array}$ & June 2000 \\
\hline $\begin{array}{l}\text { No. } 328 \text { Comparative Advertising in the Global Marketplace: The } \\
\text { Effects of Cultural Orientation on Communication }\end{array}$ & $\begin{array}{l}\text { Zeynep Gürhan-Canli and } \\
\text { Durairaj Maheswaran }\end{array}$ & Aug. 2000 \\
\hline No. 327 Post Privatization Enterprise Restructuring & Morris Bornstein & July 2000 \\
\hline No. 326 Who is Afraid of Political Instability? & $\begin{array}{l}\text { Nauro F. Campos and Jeffrey B. } \\
\text { Nugent }\end{array}$ & July 2000 \\
\hline No. 325 Business Groups, the Financial Mark & Raja Kali & June 2000 \\
\hline
\end{tabular}


Davidson Institute Working Papers are available at: www.wdi.bus.umich.edu

\begin{tabular}{|c|c|c|}
\hline $\begin{array}{l}\text { No. } 324 \text { Restructuring with What Success? A Case Study of Russian } \\
\text { Firms }\end{array}$ & Susan Linz & July 2000 \\
\hline $\begin{array}{l}\text { No. } 323 \text { Priorities and Sequencing in Privatization: Theory and } \\
\text { Evidence from the Czech Republic }\end{array}$ & $\begin{array}{l}\text { Nandini Gupta, John C. Ham and } \\
\text { Jan Svejnar }\end{array}$ & May 2000 \\
\hline $\begin{array}{l}\text { No. } 322 \text { Liquidity, Volatility, and Equity Trading Costs Across } \\
\text { Countries and Over Time }\end{array}$ & $\begin{array}{l}\text { Ian Domowitz, Jack Glen and } \\
\text { Ananth Madhavan }\end{array}$ & Mar. 2000 \\
\hline $\begin{array}{l}\text { No. } 321 \text { Equilibrium Wage Arrears: A Theoretical and Empirical } \\
\text { Analysis of Institutional Lock-In }\end{array}$ & $\begin{array}{l}\text { John S. Earle and Klara Z. } \\
\text { Sabirianova }\end{array}$ & Oct. 2000 \\
\hline No. 320 Rethinking Marketing Programs for Emerging Markets & $\begin{array}{l}\text { Niraj Dawar and Amitava } \\
\text { Chattopadhyay }\end{array}$ & June 2000 \\
\hline $\begin{array}{l}\text { No. } 319 \text { Public Finance and Low Equilibria in Transition Economies: } \\
\text { the Role of Institutions }\end{array}$ & $\begin{array}{l}\text { Daniel Daianu and Radu } \\
\text { Vranceanu }\end{array}$ & June 2000 \\
\hline $\begin{array}{l}\text { No. } 318 \text { Some Econometric Evidence on the Effectiveness of Active } \\
\text { Labour Market Programmes in East Germany }\end{array}$ & $\begin{array}{l}\text { Martin Eichler and Michael } \\
\text { Lechner }\end{array}$ & June 2000 \\
\hline No. 317 A Model of Russia's "Virtual Economy" & R.E Ericson and B.W Ickes & May 2000 \\
\hline $\begin{array}{l}\text { No. } 316 \text { Financial Institutions, Financial Contagion, and Financial } \\
\text { Crises }\end{array}$ & $\begin{array}{l}\text { Haizhou Huang and Chenggang } \\
\mathrm{Xu}\end{array}$ & Mar. 2000 \\
\hline $\begin{array}{l}\text { No. } 315 \text { Privatization versus Regulation in Developing Economies: The } \\
\text { Case of West African Banks }\end{array}$ & $\begin{array}{l}\text { Jean Paul Azam, Bruno Biais, and } \\
\text { Magueye Dia }\end{array}$ & Feb. 2000 \\
\hline $\begin{array}{l}\text { No. } 314 \text { Is Life More Risky in the Open? Household Risk-Coping and } \\
\text { the Opening of China's Labor Markets }\end{array}$ & John Giles & Apr. 2000 \\
\hline $\begin{array}{l}\text { No. } 313 \text { Networks, Migration and Investment: Insiders and Outsiders in } \\
\text { Tirupur's Production Cluster }\end{array}$ & $\begin{array}{l}\text { Abhijit Banerjee and Kaivan } \\
\text { Munshi }\end{array}$ & Mar. 2000 \\
\hline $\begin{array}{l}\text { No. } 312 \text { Computational Analysis of the Impact on India of the Uruguay } \\
\text { Round and the Forthcoming WTO Trade Negotiations }\end{array}$ & $\begin{array}{l}\text { Rajesh Chadha, Drusilla K. } \\
\text { Brown, Alan V. Deardorff and } \\
\text { Robert M. Stern }\end{array}$ & Mar. 2000 \\
\hline No. 311 Subsidized Jobs for Unemployed Workers in Slovakia & Jan. C. van Ours & May 2000 \\
\hline No. 310 Determinants of Managerial Pay in the Czech Republic & $\begin{array}{l}\text { Tor Eriksson, Jaromir Gottvald } \\
\text { and Pavel Mrazek }\end{array}$ & May 2000 \\
\hline $\begin{array}{l}\text { No. } 309 \text { The Great Human Capital Reallocation: An Empirical Analysis } \\
\text { of Occupational Mobility in Transitional Russia }\end{array}$ & Klara Z. Sabirianova & Oct. 2000 \\
\hline No. 308 Economic Development, Legality, and the Transplant Effect & $\begin{array}{l}\text { Daniel Berkowitz, Katharina } \\
\text { Pistor, and Jean-Francois Richard }\end{array}$ & Feb. 2000 \\
\hline $\begin{array}{l}\text { No. } 307 \text { Community Participation, Teacher Effort, and Educational } \\
\text { Outcome: The Case of El Salvador's EDUCO Program }\end{array}$ & Yasuyuki Sawada & Nov. 1999 \\
\hline No. 306 Gender Wage Gap and Segregation in Late Transition & Stepan Jurajda & May 2000 \\
\hline $\begin{array}{l}\text { No. } 305 \text { The Gender Pay Gap in the Transition from Communism: } \\
\text { Some Empirical Evidence }\end{array}$ & Andrew Newell and Barry Reilly & May 2000 \\
\hline No. 304 Post-Unification Wage Growth in East Germany & Jennifer Hunt & Nov. 1998 \\
\hline $\begin{array}{l}\text { No. } 303 \text { How Does Privatization Affect Workers? The Case of the } \\
\text { Russian Mass Privatization Program }\end{array}$ & Elizabeth Brainerd & May 2000 \\
\hline $\begin{array}{l}\text { No. } 302 \text { Liability for Past Environmental Contamination and } \\
\text { Privatization }\end{array}$ & Dietrich Earnhart & Mar. 2000 \\
\hline No. 301 Varieties, Jobs and EU Enlargement & $\begin{array}{l}\text { Tito Boeri and Joaquim Oliveira } \\
\text { Martins }\end{array}$ & May 2000 \\
\hline No. 300 Employer Size Effects in Russia & Todd Idson & Apr. 2000 \\
\hline $\begin{array}{l}\text { No. } 299 \text { Information Complements, Substitutes, and Strategic Product } \\
\text { Design }\end{array}$ & $\begin{array}{l}\text { Geoffrey G. Parker and Marshall } \\
\text { W. Van Alstyne }\end{array}$ & Mar. 2000 \\
\hline $\begin{array}{l}\text { No. } 298 \text { Markets, Human Capital, and Inequality: Evidence from Rural } \\
\text { China }\end{array}$ & $\begin{array}{l}\text { Dwayne Benjamin, Loren Brandt, } \\
\text { Paul Glewwe, and Li Guo }\end{array}$ & May 2000 \\
\hline No. 297 Corporate Governance in the Asian Financial Crisis & $\begin{array}{l}\text { Simon Johnson, Peter Boone, } \\
\text { Alasdair Breach, and Eric } \\
\text { Friedman }\end{array}$ & Nov. 1999 \\
\hline No. 296 Competition and Firm Performance: Lessons from Russia & J. David Brown and John S. Earle & Mar. 2000 \\
\hline No. 295 Wage Determination in Russia: An Econometric Investigation & $\begin{array}{l}\text { Peter J. Luke and Mark E. } \\
\text { Schaffer }\end{array}$ & Mar. 2000 \\
\hline
\end{tabular}


Davidson Institute Working Papers are available at: www.wdi.bus.umich.edu

\begin{tabular}{|c|c|c|}
\hline $\begin{array}{l}\text { No. 294: Can Banks Promote Enterprise Restructuring?: Evidence From } \\
\text { a Polish Bank's Experience }\end{array}$ & John P. Bonin and Bozena Leven & Mar. 2000 \\
\hline No. 293: Why do Governments Sell Privatised Companies Abroad? & $\begin{array}{l}\text { Bernardo Bortolotti, Marcella } \\
\text { Fantini and Carlo Scarpa }\end{array}$ & Mar. 2000 \\
\hline $\begin{array}{l}\text { No. 292: Going Public in Poland: Case-by-Case Privatizations, Mass } \\
\text { Privatization and Private Sector Initial Public Offerings }\end{array}$ & Wolfgang Aussenegg & Dec. 1999 \\
\hline $\begin{array}{l}\text { No. 291: Institutional Technology and the Chains of Trust: Capital } \\
\text { Markets and Privatization in Russia and the Czech Republic }\end{array}$ & Bruce Kogut and Andrew Spicer & Mar. 1999 \\
\hline No. 290: Banking Crises and Bank Rescues: The Effect of Reputation & Jenny Corbett and Janet Mitchell & Jan. 2000 \\
\hline $\begin{array}{l}\text { No. 289: Do Active Labor Market Policies Help Unemployed Workers } \\
\text { to Find and Keep Regular Jobs? }\end{array}$ & Jan C. van Ours & Feb. 2000 \\
\hline No. 288: Consumption Patterns of the New Elite in Zimbabwe & Russell Belk & Feb. 2000 \\
\hline $\begin{array}{l}\text { No. 287: Barter in Transition Economies: Competing Explanations } \\
\text { Confront Ukranian Data }\end{array}$ & $\begin{array}{l}\text { Dalia Marin, Daniel Kaufmann } \\
\text { and Bogdan Gorochowskij }\end{array}$ & Jan. 2000 \\
\hline $\begin{array}{l}\text { No. 286: The Quest for Pension Reform: Poland's Security through } \\
\text { Diversity }\end{array}$ & $\begin{array}{l}\text { Marek Góra and Michael } \\
\text { Rutkowski }\end{array}$ & Jan. 2000 \\
\hline No. 285: Disorganization and Financial Collapse & $\begin{array}{l}\text { Dalia Marin and Monika } \\
\text { Schnitzer }\end{array}$ & Oct. 1999 \\
\hline No. 284: Coordinating Changes in M-form and U-form Organizations & $\begin{array}{l}\text { Yingyi Qian, Gérard Roland and } \\
\text { Chenggang Xu }\end{array}$ & May 1999 \\
\hline $\begin{array}{l}\text { No. 283: Why Russian Workers Do Not Move: Attachment of Workers } \\
\text { Through In-Kind Payments }\end{array}$ & Guido Friebel and Sergei Guriev & Oct. 1999 \\
\hline No. 282: Lessons From Fiascos in Russian Corporate Governance & $\begin{array}{l}\text { Merritt B. Fox and Michael A. } \\
\text { Heller }\end{array}$ & Oct. 1999 \\
\hline $\begin{array}{l}\text { No. 281: Income Distribution and Price Controls: Targeting a Social } \\
\text { Safety Net During Economic Transition }\end{array}$ & $\begin{array}{l}\text { Michael Alexeev and James } \\
\text { Leitzel }\end{array}$ & Mar. 1999 \\
\hline $\begin{array}{l}\text { No. 280: Starting Positions, Reform Speed, and Economic Outcomes in } \\
\text { Transitioning Economies }\end{array}$ & William Hallagan and Zhang Jun & Jan. 2000 \\
\hline No. 279: The Value of Prominent Directors & $\begin{array}{l}\text { Yoshiro Miwa \& J. Mark } \\
\text { Ramseyer }\end{array}$ & Oct. 1999 \\
\hline No. 278: The System Paradigm & János Kornai & Apr. 1998 \\
\hline $\begin{array}{l}\text { No. 277: The Developmental Consequences of Foreign Direct } \\
\text { Investment in the Transition from Socialism to Capitalism: The } \\
\text { Performance of Foreign Owned Firms in Hungary }\end{array}$ & Lawrence Peter King & Sept. 1999 \\
\hline $\begin{array}{l}\text { No. 276: Stability and Disorder: An Evolutionary Analysis of Russia's } \\
\text { Virtual Economy }\end{array}$ & $\begin{array}{l}\text { Clifford Gaddy and Barry W. } \\
\text { Ickes }\end{array}$ & Nov. 1999 \\
\hline $\begin{array}{l}\text { No. 275: Limiting Government Predation Through Anonymous } \\
\text { Banking: A Theory with Evidence from China. }\end{array}$ & $\begin{array}{l}\text { Chong-En Bai, David D. Li, } \\
\text { Yingyi Qian and Yijiang Wang }\end{array}$ & July 1999 \\
\hline No. 274: Transition with Labour Supply & Tito Boeri & Dec. 1999 \\
\hline $\begin{array}{l}\text { No. 273: Sectoral Restructuring and Labor Mobility: A Comparative } \\
\text { Look at the Czech Republic }\end{array}$ & Vit Sorm and Katherine Terrell & Nov. 1999 \\
\hline $\begin{array}{l}\text { No. 272: Published in: Journal of Comparative Economics "Returns to } \\
\text { Human Capital Under the Communist Wage Grid and During the } \\
\text { Transition to a Market Economy" Vol. 27, pp. 33-60 1999. }\end{array}$ & $\begin{array}{l}\text { Daniel Munich, Jan Svejnar and } \\
\text { Katherine Terrell }\end{array}$ & Oct. 1999 \\
\hline $\begin{array}{l}\text { No. 271: Barter in Russia: Liquidity Shortage Versus Lack of } \\
\text { Restructuring }\end{array}$ & $\begin{array}{l}\text { Sophie Brana and Mathilde } \\
\text { Maurel }\end{array}$ & June 1999 \\
\hline $\begin{array}{l}\text { No. 270: Tests for Efficient Financial Intermediation with Application to } \\
\text { China }\end{array}$ & Albert Park and Kaja Sehrt & Mar. 1999 \\
\hline $\begin{array}{l}\text { No. 269a: Russian Privatization and Corporate Governance: What Went } \\
\text { Wrong? }\end{array}$ & $\begin{array}{l}\text { Bernard Black, Reinier Kraakman } \\
\text { and Anna Tarassova }\end{array}$ & May 2000 \\
\hline $\begin{array}{l}\text { No. 269: Russian Privatization and Corporate Governance: What Went } \\
\text { Wrong? }\end{array}$ & $\begin{array}{l}\text { Bernard Black, Reinier Kraakman } \\
\text { and Anna Tarassova }\end{array}$ & Sept. 1999 \\
\hline No. 268: Are Russians Really Ready for Capitalism? & Susan Linz & Sept. 1999 \\
\hline No. 267: Do Stock Markets Promote Economic Growth? & $\begin{array}{l}\text { Randall K. Filer, Jan Hanousek } \\
\text { and Nauro Campos }\end{array}$ & Sept. 1999 \\
\hline
\end{tabular}




\begin{tabular}{|c|c|c|}
\hline $\begin{array}{l}\text { No. 266: Objectivity, Proximity and Adaptability in Corporate } \\
\text { Governance }\end{array}$ & $\begin{array}{l}\text { Arnoud W.A Boot and Jonathan } \\
\text { R. Macey }\end{array}$ & Sept. 1999 \\
\hline $\begin{array}{l}\text { No. 265: When the Future is not What it Used to Be: Lessons from the } \\
\text { Western European Experience to Forecasting Education and Training in } \\
\text { Transitional Economies }\end{array}$ & $\begin{array}{l}\text { Nauro F. Campos, Gerard } \\
\text { Hughes, Stepan Jurajda, and } \\
\text { Daniel Munich }\end{array}$ & Sept. 1999 \\
\hline $\begin{array}{l}\text { No. 264: The Institutional Foundation of Foreign-Invested Enterprises } \\
\text { (FIEs) in China }\end{array}$ & Yasheng Huang & Sept. 1999 \\
\hline $\begin{array}{l}\text { No. 263: The Changing Corporate Governance Paradigm: Implications } \\
\text { for Transition and Developing Countries }\end{array}$ & $\begin{array}{l}\text { Erik Berglof and Ernst-Ludwig } \\
\text { von Thadden }\end{array}$ & June 1999 \\
\hline No. 262: Law Enforcement and Transition & $\begin{array}{l}\text { Gerard Roland and Thierry } \\
\text { Verdier }\end{array}$ & May 1999 \\
\hline $\begin{array}{l}\text { No. 261: Soft Budget Constraints, Pecuniary Externality, and the Dual } \\
\text { Track System }\end{array}$ & Jiahua Che & une 2000 \\
\hline $\begin{array}{l}\text { No. 260: Missing Market in Labor Quality: The Role of Quality Markets } \\
\text { in Transition }\end{array}$ & va & July \\
\hline $\begin{array}{l}\text { No. 259: Do Corporate Global Environmental Standards in Emerging } \\
\text { Markets Create or Destroy Market Value }\end{array}$ & $\begin{array}{l}\text { Glen Dowell, Stuart Hart and } \\
\text { Bernard Yeung }\end{array}$ & une 1999 \\
\hline No. 258: Public Training and Outflows from Unemployment & Patrick A. Puhani & June 1999 \\
\hline $\begin{array}{l}\text { No. 257: Ownership Versus Environment: Why are Public Sector Firms } \\
\text { Inefficient? }\end{array}$ & $\begin{array}{l}\text { Bartel a } \\
\text { on }\end{array}$ & June 1999 \\
\hline $\begin{array}{l}\text { No. 256: Taxation and Evasion in the Presence of Exortion by } \\
\text { Organized Crime }\end{array}$ & $\begin{array}{l}1 \text { Alexeev, Eckhard } \\
\text { fan Osborne }\end{array}$ & Nov. 1999 \\
\hline No. 255: Revisiting Hungary's Bankruptcy Episode & Bonin & Sept. 1999 \\
\hline No. 254: FDI i & a v.N Whitman & 1999 \\
\hline $\begin{array}{l}\text { No. 253: The Asian Financial Crisis: What Happened, and What } \\
\text { Done }\end{array}$ & $\begin{array}{l}\text { Jeffrey D. Sachs and Wing Thye } \\
\text { Woo }\end{array}$ & Jan. 1999 \\
\hline No. 252: Organizational Law as Asset Partitioning & $\begin{array}{l}\text { Henry Hansmann and Reinier } \\
\text { Kraakman }\end{array}$ & Sept. 1999 \\
\hline $\begin{array}{l}\text { No. 251: Con } \\
\text { the Case of th }\end{array}$ & $\begin{array}{l}\text { dict E. M. Steenkamp } \\
\text { en M. Burgess }\end{array}$ & Sept. 1999 \\
\hline $\begin{array}{l}\text { No. 250: Prope } \\
\text { and Production }\end{array}$ & $\begin{array}{l}\mathrm{Ma} \\
\mathrm{Brc}\end{array}$ & July 1998 \\
\hline $\begin{array}{l}\text { No. 249: Impacts of the Indonesian Economic Crisis: Price Changes and } \\
\text { the Poor }\end{array}$ & en Berry, & June 1999 \\
\hline $\begin{array}{l}\text { No. 248: Internal Barriers in the Transition of Enterprises from Central } \\
\text { Plan to Market }\end{array}$ & Charalambos Vlachoutsicos & July 1999 \\
\hline $\begin{array}{l}\text { No. 247: Spillovers from Multinationals in Developing Countries: the } \\
\text { Mechanisms at Work }\end{array}$ & Richard E. Caves & June 1999 \\
\hline $\begin{array}{l}\text { No. 246: Dynamism and Inertia on the Russian Labour Market: A } \\
\text { Model of Segmentation }\end{array}$ & $\begin{array}{l}\text { Irena Grosfeld, Claudia Senik- } \\
\text { Leygonie, Thierry Verdier, Stanislav } \\
\text { Kolenikov and Elena Paltseva }\end{array}$ & May 1999 \\
\hline No. 245: Lesso & \begin{tabular}{|l} 
John Bonin and Paul Wachtel \\
\end{tabular} & May 1999 \\
\hline $\begin{array}{l}\text { No. 244: Nominal-Real Tradeoffs and the Effects of Monetary Policy: } \\
\text { the Romanian Experience }\end{array}$ & Christian Popa & Dec. 1998 \\
\hline $\begin{array}{l}\text { No. 243: Privatization, Political Risk and Stock Market Development in } \\
\text { Emerging Economies }\end{array}$ & $\begin{array}{l}\text { Enrico C. Perotti and Pieter van } \\
\text { Oijen }\end{array}$ & Mar. 1999 \\
\hline No. 242: Investment Financing in Russian Financial-Industrial Groups & $\begin{array}{l}\text { Enrico C. Perotti and Stanislav } \\
\text { Gelfer }\end{array}$ & Oct. 1998 \\
\hline $\begin{array}{l}\text { No. 241: Can governments maintain hard budget constraints? Bank } \\
\text { lending and financial isolation in Romania }\end{array}$ & $\begin{array}{l}\text { Octavian Carare, Constantijn } \\
\text { Claessens, Enrico C. Perotti }\end{array}$ & Jan. 1999 \\
\hline $\begin{array}{l}\text { No. 240: Democratic Institutions and Economic Reform: the Polish } \\
\text { Case }\end{array}$ & $\begin{array}{l}\text { John E. Jackson, Jacek Klich, and } \\
\text { Krystyna Poznanska }\end{array}$ & Apr. 1998 \\
\hline No. 239: A Longitudinal Study of IJV Perfor & $\begin{array}{l}\text { Keith D. Brouthers and Gary } \\
\text { Bamossy }\end{array}$ & June 1999 \\
\hline
\end{tabular}




\begin{tabular}{|c|c|c|}
\hline $\begin{array}{l}\text { No. 238: Published in: Journal of Business Venturing, "Firm Creation } \\
\text { and Economic Transitions" } 14(5,6) \text { Sep/Nov 1999, pp. 427-450. }\end{array}$ & $\begin{array}{l}\text { John E. Jackson, Jacek Klich, } \\
\text { Krystyna Poznanska }\end{array}$ & July 1998 \\
\hline No. 237: Analysis of Entrepreneurial Attitudes in Poland & $\begin{array}{l}\text { John E. Jackson and Aleksander } \\
\text { S. Marcinkowski }\end{array}$ & Mar. 1997 \\
\hline $\begin{array}{l}\text { No. 236: Investment and Finance in De Novo Private Firms: Empirical } \\
\text { Results from the Czech Republic, Hungary, and Poland }\end{array}$ & $\begin{array}{l}\text { Andrzej Bratkowski, Irena } \\
\text { Grosfeld, Jacek Rostowski }\end{array}$ & Apr. 1999 \\
\hline $\begin{array}{l}\text { No. 235: Does a Soft Macroeconomic Environment Induce } \\
\text { Restructuring on the Microeconomic Level during the Transition } \\
\text { Period? Evidence from Investment Behavior of Czech Enterprises }\end{array}$ & Lubomír Lízal & June 1999 \\
\hline $\begin{array}{l}\text { No. 234: Banking Reform in China: Gradually Strengthening Pillar or } \\
\text { Fragile Reed? }\end{array}$ & John Bonin & June 1999 \\
\hline $\begin{array}{l}\text { No. 233: Theories of Soft Budget Constraints and the Analysis of } \\
\text { Banking Crises }\end{array}$ & Janet Mitchell & Mar. 1999 \\
\hline $\begin{array}{l}\text { No. 232: Unemployment Risk, Precautionary Savings, and } \\
\text { Moonlighting in Russia }\end{array}$ & $\begin{array}{l}\text { Alessandra Guariglia and Byung- } \\
\text { Yeon Kim }\end{array}$ & June 1999 \\
\hline $\begin{array}{l}\text { No. 231: Investing in Turbulent Times: The Investment Behavior of } \\
\text { Polish Firms in the Transition }\end{array}$ & $\begin{array}{l}\text { Josef C. Brada, Arthur E. King, } \\
\text { and Chia-Ying Ma }\end{array}$ & Apr. 1999 \\
\hline No. 230: The End of Moderate Inflation in Three Transition Economies? & Josef C. Brada and Ali M. Kutan & Apr. 1999 \\
\hline $\begin{array}{l}\text { No. 229: Back to the Future: The Growth Prospects of Transition } \\
\text { Economies Reconsidered }\end{array}$ & Nauro F. Campos & Apr. 1999 \\
\hline No. 228: The Enterprise Isolation Program in Russia & Simeon Djankov & Apr. 1999 \\
\hline $\begin{array}{l}\text { No. 227: Published in: Journal of Comparative Economics, "Ownership } \\
\text { Concentration and Corporate Performance in the Czech Republic" } \\
\text { 27(3), Sept. 1999, pp. 498-513. }\end{array}$ & $\begin{array}{l}\text { Stijn Claessens and Simeon } \\
\text { Djankov }\end{array}$ & Apr. 1999 \\
\hline $\begin{array}{l}\text { No. 226: Published in Journal of Population Economics, "Poland on the } \\
\text { Dole: The Effect of Reducing the Unemployment Benefit Entitlement } \\
\text { Period during Transition" 13: } 35-44,2000 .\end{array}$ & Patrick A. Puhani & Mar. 1999 \\
\hline No. 225: Transition at Whirlpool-Tatramat: Case Studies & $\begin{array}{l}\text { Hans Brechbuhl and Sonia } \\
\text { Ferencikova }\end{array}$ & Mar. 1999 \\
\hline $\begin{array}{l}\text { No. 224: Measuring Progress in Transition and Towards EU Accession: } \\
\text { A Comparison of Manufacturing Firms in Poland, Romania, and Spain }\end{array}$ & $\begin{array}{l}\text { Wendy Carlin, Saul Estrin, and } \\
\text { Mark Schaffer }\end{array}$ & Mar. 1999 \\
\hline $\begin{array}{l}\text { No. 223: Product Market Competition in Transition Economies: } \\
\text { Increasing Varieties and Consumer Loyalty }\end{array}$ & Mitsutoshi M. Adachi & Mar. 1999 \\
\hline $\begin{array}{l}\text { No. 222: Opaque Markets and Rapid Growth: the Superiority of Bank- } \\
\text { Centered Financial Systems for Developing Nations }\end{array}$ & Rodney Wallace & July 1999 \\
\hline No. 221: Technology Spillovers through Foreign Direct Investment & Yuko Kinoshita & Jan. 1999 \\
\hline $\begin{array}{l}\text { No. 220: Managerial, Expertise and Team Centered Forms of } \\
\text { Organizing: A Cross-Cultural Exploration of Independence in } \\
\text { Engineering Work }\end{array}$ & Leslie Perlow & Jan. 1999 \\
\hline $\begin{array}{l}\text { No. 219: Household Structure and Labor Demand in Agriculture: } \\
\text { Testing for Separability in Rural China }\end{array}$ & $\begin{array}{l}\text { Audra J. Bowlus and Terry } \\
\text { Sicular }\end{array}$ & Jan. 1999 \\
\hline $\begin{array}{l}\text { No. 218: Competing Strategies of FDI and Technology Transfer to } \\
\text { China: American and Japanese Firms }\end{array}$ & $\begin{array}{l}\text { W. Mark Fruin and Penelope } \\
\text { Prime }\end{array}$ & Jan. 1999 \\
\hline $\begin{array}{l}\text { No. } 217 \text { Published in: Journal of Comparative Economics, "Returns to } \\
\text { Mobility in the Transition to a Market Economy" 27(1), Mar } 1999 .\end{array}$ & $\begin{array}{l}\text { Tito Boeri and Christopher J. } \\
\text { Flinn }\end{array}$ & Jan. 1999 \\
\hline $\begin{array}{l}\text { No. } 216 \text { Published in: Journal of Comparative Economics, "Labor } \\
\text { Market Policies and Unemployment in the Czech Republic." 27(1), Mar } \\
\text { 1999, pp. 33-60. }\end{array}$ & Katherine Terrell and Vit Sorm & Nov. 1998 \\
\hline $\begin{array}{l}\text { No. } 215 \text { Published in: Journal of Comparative Economics, "Active } \\
\text { Labor Market Policies in Poland: Human Capital Enhancement, } \\
\text { Stigmatization or Benefit Churning?" 27(1), Mar 1999, pp. 61-. }\end{array}$ & $\begin{array}{l}\text { Jochen Kluve, Hartmut Lehmann, } \\
\text { and Christoph M. Schmidt }\end{array}$ & Dec. 1998 \\
\hline $\begin{array}{l}\text { No. } 214 \text { Published in: Journal of Comparative Economics, "Does the } \\
\text { Slovenian Public Work Program Increase Participants' Chances to Find } \\
\text { a Job?" 27(1), Mar 1999, pp. 113-. }\end{array}$ & Milan Vodopivec & Dec. 1998 \\
\hline
\end{tabular}




\begin{tabular}{|c|c|c|}
\hline $\begin{array}{l}\text { No. } 213 \text { Published in: Journal of Comparative Economics, "Effects of } \\
\text { Active Labor Market Programs on the Transition Rate from } \\
\text { Unemployment into Regular Jobs in the Slovak Republic." 27(1), Mar } \\
\text { 1999, pp. 90- . }\end{array}$ & $\begin{array}{l}\text { Martina Lubyova and Jan C. van } \\
\text { Ours }\end{array}$ & Dec. 1998 \\
\hline $\begin{array}{l}\text { No. 212: The Marketing System in Bulgarian Livestock Production - } \\
\text { The Present State and Evolutionary Processes During the Period of } \\
\text { Economic Transition }\end{array}$ & Yordan Staykov, Team Leader & Oct. 1998 \\
\hline No. 211: Bankruptcy Experience in Hungary and the Czech Republic & Janet Mitchell & Oct. 1998 \\
\hline $\begin{array}{l}\text { No 210: Values, Optimum Stimulation Levels and Brand Loyalty: New } \\
\text { Scales in New Populations }\end{array}$ & $\begin{array}{l}\text { Steven M. Burgess and Mari } \\
\text { Harris }\end{array}$ & Sept. 1998 \\
\hline No. 209: Inherited Wealth, Corporate Control and Economic Growth & $\begin{array}{l}\text { Randall K. Morck, David A. } \\
\text { Stangeland, and Bernard Yeung }\end{array}$ & Sept. 1998 \\
\hline $\begin{array}{l}\text { No. 208: A Cultural Analysis of Homosocial Reproduction and } \\
\text { Contesting Claims to Competence in Transitional Firms }\end{array}$ & Michael D. Kennedy & July 1998 \\
\hline $\begin{array}{l}\text { No. 207: From Survival to Success: The Journey of Corporate } \\
\text { Transformation at Haier. Forthcoming in Managing Organizational } \\
\text { Change in Transition Economies ed. Daniel Denison. }\end{array}$ & $\begin{array}{l}\text { Arthur Yeung and Kenneth } \\
\text { DeWoskin }\end{array}$ & July 1998 \\
\hline $\begin{array}{l}\text { No. 206: Why Do People Work If They Are Not Paid? An Example } \\
\text { from Eastern Europe. Forthcoming in Managing Organizational Change } \\
\text { in Transition Economies. }\end{array}$ & Irina L. Zinovieva & May 1998 \\
\hline $\begin{array}{l}\text { No. 205: Firm Ownership and Work Motivation in Bulgaria and } \\
\text { Hungary: An Empirical Study of the Transition in the Mid-1990s. } \\
\text { Forthcoming in Managing Organizational Change in Transition } \\
\text { Economies ed. Daniel Denison. }\end{array}$ & $\begin{array}{l}\text { Robert A. Roe, Irina L. } \\
\text { Zinovieva, Elizabeth Dienes, and } \\
\text { Laurens A. ten Horn }\end{array}$ & May 1998 \\
\hline $\begin{array}{l}\text { No. 204: Human Resource Management in the Restructuring of Chinese } \\
\text { Joint Ventures. Forthcoming in Managing Organizational Change in } \\
\text { Transition Economies ed. Daniel Denison. }\end{array}$ & Nandani Lynton & Apr. 1998 \\
\hline $\begin{array}{l}\text { No. 203: Emergent Compensation Strategies in Post-Socialist Poland: } \\
\text { Understanding the Cognitive Underpinnings of Management Practices } \\
\text { in a Transition Economy. Forthcoming in Managing Organizational } \\
\text { Change in Transition Economies ed. Daniel Denison. }\end{array}$ & Marc Weinstein & Mar. 1998 \\
\hline $\begin{array}{l}\text { No. 202: Corporate Transformation and Organizational Learning: The } \\
\text { People's Republic of China. Forthcoming in Managing Organizational } \\
\text { Change in Transition Economies ed. Daniel Denison. }\end{array}$ & $\begin{array}{l}\text { Meinolf Dierkes and Zhang } \\
\text { Xinhua }\end{array}$ & Mar. 1998 \\
\hline $\begin{array}{l}\text { No. 201: Foreign Direct Investment as a Factor of Change: The Case of } \\
\text { Slovakia. Forthcoming in Managing Organizational Change in } \\
\text { Transition Economies ed. Daniel Denison. }\end{array}$ & Sonia Ferencikova & Feb. 1998 \\
\hline $\begin{array}{l}\text { No. 200: Radical versus Incremental Change: The Role of Capabilities, } \\
\text { Competition, and Leaders. Forthcoming in Managing Organizational } \\
\text { Change in Transition Economies ed. Daniel Denison. }\end{array}$ & Karen L. Newman & Feb. 1998 \\
\hline $\begin{array}{l}\text { No. 199: The Emergence of Market Practices in China's Economic } \\
\text { Transition: Price Setting Practices in Shanghai's Industrial Firms. } \\
\text { Forthcoming in Managing Organizational Change in Transition } \\
\text { Economies ed. Daniel Denison. }\end{array}$ & Douglas Guthrie & Feb. 1998 \\
\hline $\begin{array}{l}\text { No. 198: The Application of Change Management Methods at Business } \\
\text { Organizations Operating in Hungary: Challenges in the Business and } \\
\text { Cultural Environment and First Practical Experiences. Forthcoming in } \\
\text { Managing Organizational Change in Transition Economies ed. Daniel } \\
\text { Denison. }\end{array}$ & Dr. János Fehér & Jan. 1998 \\
\hline $\begin{array}{l}\text { No. 197: Organizational Changes in Russian Industrial Enterprises: } \\
\text { Mutation of Decision-Making Structures and Transformations of } \\
\text { Ownership. Forthcoming in Managing Organizational Change in } \\
\text { Transition Economies ed. Daniel Denison. }\end{array}$ & Igor B. Gurkov & Jan. 1998 \\
\hline $\begin{array}{l}\text { No. 196: Understanding and Managing Challenges to the Romanian } \\
\text { Companies during Transition. Forthcoming in Managing Organizational } \\
\text { Change in Transition Economies ed. Daniel Denison. }\end{array}$ & $\begin{array}{l}\text { Dan Candea and Rodica M. } \\
\text { Candea }\end{array}$ & Jan. 1998 \\
\hline
\end{tabular}


No. 195: Insider Lending and Economic Transition: The Structure,

Lisa A. Keister

Dec. 1997

Function, and Performance Impact of Finance Companies in Chinese

Business Groups. Forthcoming in Managing Organizational Change in

Transition Economies ed. Daniel Denison.

No. 194: Japanese Investment in Transitional Economies:

Characteristics and Performance. Forthcoming in Managing

Organizational Change in Transition Economies ed. Daniel Denison.

No. 193: Building Successful Companies in Transition Economies.

Forthcoming in Managing Organizational Change in Transition

Economies ed. Daniel Denison.

No. 192: Russian Communitariansim: An Invisible Fist in the

Transformation Process of Russia. Forthcoming in Managing

Organizational Change in Transition Economies ed. Daniel Denison.

No. 191: Teaching the Dinosaurs to Dance

No. 190: Strategic Restructuring: Making Capitalism in Post-

Communist Eastern Europe. Forthcoming in Managing Organizational

Change in Transition Economies ed. Daniel Denison.

No. 189: Published in: Regional Science and Urban Economics,

"Russia's Internal Border." 29(5), Sept. 1999.

No. 187: Corporate Structure and Performance in Hungary

No. 186: Performance of Czech Companies by Ownership Structure

No. 185: Firm Performance in Bulgaria and Estonia: The effects of competitive pressure, financial pressure and disorganisation

No. 184: Investment and Wages during the Transition: Evidence from Slovene Firms

No. 183: Investment Portfolio under Soft Budget: Implications for Growth, Volatility and Savings

No. 181: Delegation and Delay in Bank Privatization

No. 180: Financing Mechanisms and R\&D Investment

No. 179: Organizational Culture and Effectiveness: The Case of Foreign

Firms in Russia

No. 178: Output and Unemployment Dynamics in Transition

No. 177: Published in: Economics of Transition, "Bureaucracies in the

Russian Voucher Privatization." 8(1), 2000, pp. 37-57.

No. 176: Chronic Moderate Inflation in Transition: The Tale of Hungary

No. 175: Privatisation and Market Structure in a Transition Economy

No. 174: Ownership and Managerial Competition: Employee, Customer,

or Outside Ownership

No. 173: Intragovernment Procurement of Local Public Good: A

Theory of Decentralization in Nondemocratic Government

No. 172: Political Instability and Growth in Proprietary Economies

No. 171: Published in Post-Communist Economies, "Framework Issues

in the Privatization Strategies of the Czech Republic, Hungary, and

Poland" 11(1) Mar. 1999.

No. 170: Published in: European Journal of Political Economy

"Privatization, Ownership Structure and Transparency: How to Measure

a Real Involvement of the State" 15(4), Nov. 1999, pp. 605-18.

No. 169 Published in: American Economic Review, "Unemployment and the Social Safety Net during Transitions to a Market Economy:

Evidence from Czech and Slovak Men” 88(5), Dec 1998, pp. 1117-1142

\begin{tabular}{|l|l|}
\hline Paul W. Beamish and Andrew & Nov. 1997
\end{tabular}

Delios

Dr. Ivan Perlaki

Jan. 1998

Charalambos Vlachoutsicos

July 1998

Michal Cakrt

Sept. 1997

Lawrence P. King

Sept. 1997

Daniel Berkowitz and David N.

July 1998

DeJong

László Halpern and Gábor Kórsöi $\quad$ July 1998

\begin{tabular}{|l|l|}
\hline Andrew Weiss and Georgiy & June 1998
\end{tabular}

Nikitin

\begin{tabular}{|l|l|}
\hline Jozef Konings & July 1998
\end{tabular}

Janez Prasnikar and Jan Svejnar $\quad$ July 1998

\begin{tabular}{|l|l|}
\hline Chongen Bai and Yijiang Wang & July 1998
\end{tabular}

\begin{tabular}{|l|l}
\hline Loránd Ambrus-Lakatos and & July 1998
\end{tabular}

Ulrich Hege

\begin{tabular}{|l|l}
\hline Haizhou Huang and Chenggang & July 1998
\end{tabular}

$\mathrm{Xu}$

\begin{tabular}{|l|l|}
\hline Carl F. Fey and Daniel R. & Jan. 1999
\end{tabular}

Denison

Vivek H. Dehejia and Douglas W. Jan. 1998

Dwyer

\begin{tabular}{|l|l|}
\hline Guido Friebel & June 1998
\end{tabular}

János Vincze

June 1998

\begin{tabular}{|l|l}
\hline John Bennett and James Maw & June 1998 \\
\hline
\end{tabular}

\begin{tabular}{|l|l}
\hline Patrick Bolton and Chenggang & June 1998
\end{tabular}

$\mathrm{Xu}$

\begin{tabular}{|l|l|}
\hline Chong-en Bai, Yu Pan and & June 1998
\end{tabular}

Yijiang Wang

\begin{tabular}{|l|l|}
\hline Jody Overland and Michael & Aug. 1998
\end{tabular}

Spagat

\begin{tabular}{|l|l|}
\hline Morris Bornstein & June 1998
\end{tabular}

Frantisek Turnovec

May 1998

John C. Ham, Jan Svejnar, and

Dec. 1998

Katherine Terrell 
Davidson Institute Working Papers are available at: www.wdi.bus.umich.edu

\begin{tabular}{|c|c|c|}
\hline $\begin{array}{l}\text { No. 167: Voucher Privatization with Investment Funds: An Institutional } \\
\text { Analysis }\end{array}$ & David Ellerman & Mar. 1998 \\
\hline $\begin{array}{l}\text { No. 166: Published in: Marketing Issues in Transitional Economies, } \\
\text { "Value Priorities and Consumer Behavior in a Transitional Economy: } \\
\text { The Case of South Africa" ed. Rajeev Batra. }\end{array}$ & $\begin{array}{l}\text { Steven M. Burgess and Jan- } \\
\text { Benedict E.M. Steenkamp }\end{array}$ & Aug. 1998 \\
\hline $\begin{array}{l}\text { No. 164: Finance and Investment in Transition: Czech Enterprises, } \\
\text { 1993-1994 }\end{array}$ & $\begin{array}{l}\text { Ronald Anderson and Chantal } \\
\text { Kegels }\end{array}$ & Sept. 1997 \\
\hline $\begin{array}{l}\text { No. 163: European Union Trade and Investment Flows U-Shaping } \\
\text { Industrial Output in Central and Eastern Europe: Theory and Evidence }\end{array}$ & $\begin{array}{l}\text { Alexander Repkine and Patrick P. } \\
\text { Walsh }\end{array}$ & Apr. 1998 \\
\hline $\begin{array}{l}\text { No. 162: Skill Acquisition and Private Firm Creation in Transition } \\
\text { Economies }\end{array}$ & Zuzana Brixiova and Wenli Li & Oct. 1999 \\
\hline No. 161: Corruption in Transition & Susanto Basu and David D. Li & May 1998 \\
\hline $\begin{array}{l}\text { No. 160a: Tenures that Shook the World: Worker Turnover in Russia, } \\
\text { Poland and Britain }\end{array}$ & $\begin{array}{l}\text { Hartmut Lehmann and Jonathan } \\
\text { Wadsworth }\end{array}$ & Nov. 1999 \\
\hline $\begin{array}{l}\text { No. 160: Tenures that Shook the World: Worker Turnover in the } \\
\text { Russian Federation and Poland }\end{array}$ & $\begin{array}{l}\text { Hartmut Lehmann and Jonathan } \\
\text { Wadsworth }\end{array}$ & June 1998 \\
\hline No. 159: Does Market Structure Matter? New Evidence from Russia & $\begin{array}{l}\text { Annette N. Brown and J. David } \\
\text { Brown }\end{array}$ & June 1998 \\
\hline $\begin{array}{l}\text { No. 158: Structural Adjustment and Regional Long Term } \\
\text { Unemployment in Poland }\end{array}$ & $\begin{array}{l}\text { Hartmut Lehmann and Patrick P. } \\
\text { Walsh }\end{array}$ & June 1997 \\
\hline $\begin{array}{l}\text { No. 157: Baby Boom or Bust? Changing Fertility in Post-Communist } \\
\text { Czech Republic and Slovakia }\end{array}$ & Robert S. Chase & Apr. 1998 \\
\hline $\begin{array}{l}\text { No. } 156 \text { Published in: Leadership and Organization Development } \\
\text { Journal, "Leading Radical Change in Transition Economies." Vol. 19, } \\
\text { No. 6, 1998, pp. 309-324. }\end{array}$ & Karen L. Newman & June 1998 \\
\hline $\begin{array}{l}\text { No. } 155 \text { Published in: Oxford Review of Economic Policy, "From } \\
\text { Theory into Practice? Restructuring and Dynamism in Transition } \\
\text { Economies." Vol. 13, No. 2, Summer 1997, pp. 77-105. }\end{array}$ & $\begin{array}{l}\text { Wendy Carlin and Michael } \\
\text { Landesmann }\end{array}$ & June 1997 \\
\hline $\begin{array}{l}\text { No. 154: The Model and the Reality: Assessment of Vietnamese SOE } \\
\text { Reform-Implementation at the Firm Level }\end{array}$ & $\begin{array}{l}\text { Edmund Malesky, Vu Thanh } \\
\text { Hung, Vu Thi Dieu Anh, and } \\
\text { Nancy K. Napier }\end{array}$ & July 1998 \\
\hline $\begin{array}{l}\text { No. } 153 \text { Published in: Journal of Comparative Economics, "Causes of } \\
\text { the Soft Budget Constraint: Evidence on Three Explanations." Vol. 26, } \\
\text { No. 1, Mar. 1998, pp. 104-116. }\end{array}$ & David D. Li and Minsong Liang & Mar. 1998 \\
\hline $\begin{array}{l}\text { No. } 152 \text { Published in: Comparative Economic Studies, "Enterprise } \\
\text { Restructuring in Russia's Transition Economy: Formal and Informal } \\
\text { Mechanisms." Vol. 40, No. 2, Summer 1998, pp. 5-52. }\end{array}$ & Susan J. Linz and Gary Krueger & Apr. 1998 \\
\hline $\begin{array}{l}\text { No. 151: Labor Productivity in Transition: A Regional Analysis of } \\
\text { Russian Industry }\end{array}$ & Susan J. Linz & May 1998 \\
\hline $\begin{array}{l}\text { No. 150: Tax Avoidance and the Allocation of Credit. Forthcoming in } \\
\text { Financial Systems in Transition: The Design of Financial Systems in } \\
\text { Central Europe eds. Anna Meyendorff and Anjan Thakor. }\end{array}$ & Anna Meyendorff & June 1998 \\
\hline $\begin{array}{l}\text { No. 149: Commitment, Versatility and Balance: Determinants of Work } \\
\text { Time Standards and Norms in a Multi-Country Study of Software } \\
\text { Engineers }\end{array}$ & Leslie Perlow and Ron Fortgang & Apr. 1998 \\
\hline $\begin{array}{l}\text { No. 148: Changes in Poland's Transfer Payments in the 1990s: the Fate } \\
\text { of Pensioners }\end{array}$ & Bozena Leven & June 1998 \\
\hline $\begin{array}{l}\text { No. 147: Environmental Protection and Economic Development: The } \\
\text { Case of the Huaihe River Basin Cleanup Plan }\end{array}$ & $\begin{array}{l}\text { Robert Letovsky, Reze Ramazani, } \\
\text { and Debra Murphy }\end{array}$ & June 1998 \\
\hline $\begin{array}{l}\text { No. 146: Chief Executive Compensation During Early Transition: } \\
\text { Further Evidence from Bulgaria }\end{array}$ & $\begin{array}{l}\text { Derek C. Jones, Takao Kato, and } \\
\text { Jeffrey Miller }\end{array}$ & June 1998 \\
\hline $\begin{array}{l}\text { No. } 145 \text { Published in: Economics of Transition, "Women's } \\
\text { Unemployment During the Transition: Evidence from Czech and Slovak } \\
\text { Micro Data," Vol. 7, No. 1, May 1999, pp. 47-78. }\end{array}$ & $\begin{array}{l}\text { John Ham, Jan Svejnar, and } \\
\text { Katherine Terrell }\end{array}$ & May 1998 \\
\hline No. 144: Investment and Wages in Slovenia & Janez Prasnikar & May 1998 \\
\hline
\end{tabular}




\begin{tabular}{|c|c|c|}
\hline $\begin{array}{l}\text { No. } 143 \text { Published in: Review of Financial Studies, "Optimal } \\
\text { Bankruptcy Laws Across Different Economic Systems," 12(2), 47-77, } \\
\text { Summer } 19993 .\end{array}$ & $\begin{array}{l}\text { Elazar Berkovitch and Ronen } \\
\text { Israel }\end{array}$ & Mar. 1998 \\
\hline $\begin{array}{l}\text { No. 142: Industrial Policy and Poverty in Transition Economies: Two } \\
\text { Steps Forward or One Step Back? }\end{array}$ & Susan J. Linz & Mar. 1998 \\
\hline $\begin{array}{l}\text { No. } 141 \text { Collective Ownership and Privatization of China's Village } \\
\text { Enterprises }\end{array}$ & Suwen Pan and Albert Park & Apr. 1998 \\
\hline $\begin{array}{l}\text { No. } 140 \text { A Comparative Look at Labor Mobility in the Czech Republic: } \\
\text { Where have all the Workers Gone? }\end{array}$ & Vit Sorm and Katherine Terrell & Apr. 1999 \\
\hline $\begin{array}{l}\text { No. } 139 \text { The Failure of the Government-Led Program of Corporate } \\
\text { Reorganization in Romania }\end{array}$ & $\begin{array}{l}\text { Simeon Djankov and Kosali } \\
\text { Ilayperuma }\end{array}$ & Sept. 1997 \\
\hline No. 138 Ownership and Employment in Russian Industry: 1992-1995 & Susan J. Linz & Mar. 1998 \\
\hline $\begin{array}{l}\text { No. } 137 \text { Published in: Journal of Political Economy, "Reform Without } \\
\text { Losers: An Interpretation of China's Dual-Track Approach to } \\
\text { Transition," Feb. 2000; Vol. 108, Iss.1; pg. } 120\end{array}$ & $\begin{array}{l}\text { Lawrence J. Lau, Yingyi Qian, } \\
\text { and Gerard Roland }\end{array}$ & Nov. 1997 \\
\hline $\begin{array}{l}\text { No. } 136 \text { Published in: European Economic Review, "The Political } \\
\text { Economy of Mass Privatization and the Risk of Expropriation," 44(2), } \\
\text { Feb. 2000, pgs. } 393-421\end{array}$ & Klaus M. Schmidt & Mar. 1998 \\
\hline $\begin{array}{l}\text { No. 135: Radical Organizational Change: The Role of Starting } \\
\text { Conditions, Competition, and Leaders }\end{array}$ & Karen L. Newman & Jan. 1998 \\
\hline $\begin{array}{l}\text { No. 134: To Restructure or Not to Restructure: Informal Activities and } \\
\text { Enterprise Behavior in Transition }\end{array}$ & $\begin{array}{l}\text { Clifford Gaddy and Barry W. } \\
\text { Ickes }\end{array}$ & May 1998 \\
\hline No. 133: Management 101: Behavior of Firms in Transition Economies & \begin{tabular}{|l|} 
Josef C. Brada \\
\end{tabular} & Mar. 1998 \\
\hline $\begin{array}{l}\text { No. 132 Published in: Quarterly Journal of Economics, "Interfirm } \\
\text { Relationships and Informal Credit in Vietnam," 114(4), Nov. 1999, pgs. } \\
1285-1320\end{array}$ & $\begin{array}{l}\text { John McMillan and Christopher } \\
\text { Woodruff }\end{array}$ & Feb. 1998 \\
\hline $\begin{array}{l}\text { No. } 131 \text { Published in: Comparative Economic Studies, "Will } \\
\text { Restructuring Hungarian Companies Innovate? An Investigation Based } \\
\text { on Joseph Berliner's Analysis of Innovation in Soviet Industry." Vol. } \\
\text { 40, No. 2, Summer 1998, pp. 53-74. }\end{array}$ & John B. Bonin and Istvan Abel & Mar. 1998 \\
\hline $\begin{array}{l}\text { No. 130: Published in The American Economic Review, "Changing } \\
\text { Incentives of the Chinese Bureaucracy." May, } 1998 .\end{array}$ & David D. Li & Jan. 1998 \\
\hline $\begin{array}{l}\text { No. 129: Restructuring Investment in Transition: A Model of the } \\
\text { Enterprise Decision }\end{array}$ & Richard E. Ericson & Jan. 1998 \\
\hline $\begin{array}{l}\text { No. } 128 \text { Published in: Comparative Economic Studies, "Job Rights in } \\
\text { Russian Firms: Endangered or Extinct Institutions?" Vol. 40, No. 4, } \\
\text { Winter 1998, pp. 1-32. }\end{array}$ & Susan J. Linz & Jan. 1998 \\
\hline No. 127: Accounting for Growth in Post-Soviet Russia & $\begin{array}{l}\text { Daniel Berkowitz and David N. } \\
\text { DeJong }\end{array}$ & Jan. 1998 \\
\hline $\begin{array}{l}\text { No. } 126 \text { Published in: Economics of Transition, "From Federalism, } \\
\text { Chinese Style, to Privatization Chinese Style," } 7(1), 1999 \text {, pgs. 103-31 }\end{array}$ & $\begin{array}{l}\text { Yuanzheng Cao, Yingyi Qian, } \\
\text { and Barry R. Weingast }\end{array}$ & Dec. 1997 \\
\hline $\begin{array}{l}\text { No. 125: Market Discipline in Conglomerate Banks: Is an Internal } \\
\text { Allocation of Cost of Capital Necessary as Incentive Device? } \\
\text { Forthcoming in Financial Systems in Transition: The Design of } \\
\text { Financial Systems in Central Europe eds. Anna Meyendorff and Anjan } \\
\text { Thakor. }\end{array}$ & $\begin{array}{l}\text { Arnoud W. A. Boot and Anjolein } \\
\text { Schmeits }\end{array}$ & Nov. 1997 \\
\hline $\begin{array}{l}\text { No. 124: Financial Discipline in the Enterprise Sector in Transition } \\
\text { Countries: How Does China Compare? }\end{array}$ & $\begin{array}{l}\text { Shumei Gao and Mark E. } \\
\text { Schaffer }\end{array}$ & Feb. 1998 \\
\hline $\begin{array}{l}\text { No. 123: Considerations of an Emerging Marketplace: Managers' } \\
\text { Perceptions in the Southern African Economic Community }\end{array}$ & Brent Chrite and David Hudson & Feb. 1998 \\
\hline No. 122: A Model of the Informal Economy in Transition Economies & $\begin{array}{l}\text { Simon Commander and Andrei } \\
\text { Tolstopiatenko }\end{array}$ & Nov. 1997 \\
\hline $\begin{array}{l}\text { No. 121: Local Labour Market Dynamics in the Czech and Slovak } \\
\text { Republics }\end{array}$ & $\begin{array}{l}\text { Peter Huber and Andreas } \\
\text { Worgotter }\end{array}$ & Nov. 1997 \\
\hline $\begin{array}{l}\text { No. 119: Published in Academy of Management Review, "Organizational } \\
\text { Transformation during Institutional Upheaval," } 25 \text { (3), 2000, p. 602-619 }\end{array}$ & Karen L. Newman & Mar. 1998 \\
\hline
\end{tabular}




\begin{tabular}{|c|c|c|}
\hline No. 118: Industrial Decline and Labor Reallocation in Romania & John S. Earle & Oct. 1997 \\
\hline No. 117: Notes for an Essay on the Soft Budget Constraint & Lorand Ambrus-Lakatos & Jan. 1997 \\
\hline No. 116: Labor Demand During Transition in Hungary & Gabor Korosi & Oct. 1997 \\
\hline No. 115: Enterprise Performance and Managers' Profiles & $\begin{array}{l}\text { Simeon Djankov and Stijn } \\
\text { Claessens }\end{array}$ & Dec. 1997 \\
\hline $\begin{array}{l}\text { No. 114b Employment and Wages in Enterprises under Communism } \\
\text { and in Transition: Evidence From Central Europe and Russia }\end{array}$ & $\begin{array}{l}\text { Swati Basu, Saul Estrin, and Jan } \\
\text { Svejnar }\end{array}$ & Apr. 2000 \\
\hline $\begin{array}{l}\text { No. 114: Employment and Wage Behavior of Enterprises in Transitional } \\
\text { Economies }\end{array}$ & $\begin{array}{l}\text { Swati Basu, Saul Estrin, and Jan } \\
\text { Svejnar }\end{array}$ & Oct. 1997 \\
\hline $\begin{array}{l}\text { No. 113: Preliminary Evidence on Active Labor Programs' Impact in } \\
\text { Hungary and Poland }\end{array}$ & Christopher J. O’Leary & Oct. 1997 \\
\hline $\begin{array}{l}\text { No. 111: Unemployment Benefits and Incentives in Hungary: New } \\
\text { Evidence }\end{array}$ & Joachim Wolff & Oct. 1997 \\
\hline $\begin{array}{l}\text { No. 110: Published in: Empirical Economics, "Long-Term } \\
\text { Unemployment, Unemployment Benefits and Social Assistance: The } \\
\text { Polish Experience" Empirical-Economics; 23(1-2), 1998, pp. 55-85. }\end{array}$ & $\begin{array}{l}\text { Marek Gora and Christoph M. } \\
\text { Schmidt }\end{array}$ & Apr. 1997 \\
\hline $\begin{array}{l}\text { No. } 109 \text { Published in: Industrial and Labor Relations Review, "Markets } \\
\text { for Communist Human Capital: Returns to Education and Experience in } \\
\text { Post-Communist Czech Republic and Slovakia." 51(3), Apr. 1998, pp. } \\
\text { 401-423. }\end{array}$ & Robert S. Chase & Oct. 1997 \\
\hline $\begin{array}{l}\text { No. 107: The Worker-Firm Matching in the Transition: (Why) Are the } \\
\text { Czechs More Successful Than Others? }\end{array}$ & $\begin{array}{l}\text { Daniel Münich, Jan Svejnar, and } \\
\text { Katherine Terrell }\end{array}$ & 1997 \\
\hline $\begin{array}{l}\text { No. } 106 \text { Published in: Journal of Comparative Economics, "Job } \\
\text { Creation, Job Destruction and Growth of Newly Established, Privatized } \\
\text { and State-Owned Enterprises in Transition Economies: Survey Evidence } \\
\text { from Bulgaria, Hungary, and Romania," 26(3), Sept. 1998, pp. 429-445. }\end{array}$ & $\begin{array}{l}\text { Valentijn Bilsen and Jozef } \\
\text { Konings }\end{array}$ & Sept. 1998 \\
\hline $\begin{array}{l}\text { No. 105: Getting Behind the East-West [German] Wage Differential: } \\
\text { Theory and Evidence }\end{array}$ & $\begin{array}{l}\text { Michael Burda and Christoph } \\
\text { Schmidt }\end{array}$ & May 1997 \\
\hline No. 104: The Birth of the "Wage Curve" in Hungary, 1989-95 & Gabor Kertesi and Janos Kollo & Oct. 1997 \\
\hline $\begin{array}{l}\text { No. 103: Published in: Journal of Comparative Economics, "Grime and } \\
\text { Punishment: Job Insecurity and Wage Arrears in the Russian } \\
\text { Federation" 27, 595-617 (1999). }\end{array}$ & $\begin{array}{l}\text { Hartmut Lehmann, Jonathan } \\
\text { Wadsworth, and Alessandro } \\
\text { Acquisti }\end{array}$ & Oct. 1997 \\
\hline No. 102: Social Networks in Transition & $\begin{array}{l}\text { Lorena Barberia, Simon Johnson, } \\
\text { and Daniel Kaufmann }\end{array}$ & Oct. 1997 \\
\hline $\begin{array}{l}\text { No. 101: Depreciation and Russian Corporate Finance: A Pragmatic } \\
\text { Approach to Surviving the Transition }\end{array}$ & Susan J. Linz & Nov. 1997 \\
\hline No. 100: Romanian Financial System Reform & $\begin{array}{l}\text { Anna Meyendorff and Anjan V. } \\
\text { Thakor }\end{array}$ & Nov. 1997 \\
\hline $\begin{array}{l}\text { No. 99: Proceedings of the Conference on Strategic Alliances in } \\
\text { Transitional Economies, held May 20, } 1997 \text { at the Davidson Institute }\end{array}$ & Edited by Cynthia Koch & May 1997 \\
\hline No. 98: Institutions, Strain and the Underground Economy & Daniel Daianu and Lucian Albu & Nov. 1997 \\
\hline No. 97: Structure and Strain in Explaining Inter-Enterprise Arrears & Daniel Daianu & Nov. 1997 \\
\hline $\begin{array}{l}\text { No. 96: Resource Misallocation and Strain: Explaining Shocks in Post- } \\
\text { Command Economies }\end{array}$ & Daniel Daianu & Nov. 1997 \\
\hline $\begin{array}{l}\text { No. 95: Published in: Finance-a-Uver, "Czech Money Market: Emerging } \\
\text { Links Among Interest Rates." 48(2) } 1998 \text { pp. 99-109. }\end{array}$ & $\begin{array}{l}\text { Jan Hanousek and Evzen } \\
\text { Kocenda }\end{array}$ & Nov. 1997 \\
\hline $\begin{array}{l}\text { No. 94: Pre-Reform Industry and the } \\
\text { State Monopsony in China }\end{array}$ & $\begin{array}{l}\text { Xiao-Yuan Dong and Louis } \\
\text { Putterman }\end{array}$ & Oct. 1997 \\
\hline $\begin{array}{l}\text { No. 93: China's State-Owned Enterprises } \\
\text { In the First Reform Decade: } \\
\text { An Analysis of a Declining Monopsony }\end{array}$ & $\begin{array}{l}\text { Xiao-Yuan Dong and Louis } \\
\text { Putterman }\end{array}$ & Oct. 1997 \\
\hline No. 92: Expatriate Management in the Czech Republic & Richard B. Peterson & Sept. 1997 \\
\hline No. 91: China and the Idea of Economic Reform & Thomas G. Rawski & Apr. 1997 \\
\hline $\begin{array}{l}\text { No. } 90 \text { Published in: China Economic Review, "China's State Enterprise } \\
\text { Reform: An Overseas Perspective." Vol. 8, Spring 1997, pp. 89-98. }\end{array}$ & Thomas G. Rawski & July 1997 \\
\hline
\end{tabular}




\begin{tabular}{|c|c|c|}
\hline $\begin{array}{l}\text { No. 89: The Economic Determinants of Internal Migration Flows in } \\
\text { Russia During Transition }\end{array}$ & Annette N. Brown & July 1997 \\
\hline $\begin{array}{l}\text { No. 88: Gender Wage Gaps in China's Labor Market: Size, Structure, } \\
\text { Trends }\end{array}$ & $\begin{array}{l}\text { Margaret Maurer-Fazio, Thomas } \\
\text { G. Rawski, and Wei Zhang }\end{array}$ & July 1997 \\
\hline No. 87: Privatisation in Central and Eastern Europe & Saul Estrin & June 1997 \\
\hline $\begin{array}{l}\text { No. 86: Published in : Economics of Transition, "The Effect of } \\
\text { Privatization on Wealth Distribution in Russia." v. 7, no. 2, 1999, pp. } \\
449-65\end{array}$ & Michael Alexeev & Feb. 1998 \\
\hline $\begin{array}{l}\text { No. 85: Was Privatization in Eastern Germany a Special Case? Some } \\
\text { Lessons from the Treuhand }\end{array}$ & Uwe Siegmund & Sept. 1997 \\
\hline No. 84: Start-ups and Transition & $\begin{array}{l}\text { Daniel M. Berkowitz and David J. } \\
\text { Cooper }\end{array}$ & Sept. 1997 \\
\hline $\begin{array}{l}\text { No. 83: Which Enterprises (Believe They) Have Soft Budgets after } \\
\text { Mass Privatization? Evidence from Mongolia }\end{array}$ & $\begin{array}{l}\text { James Anderson, Georges } \\
\text { Korsun, and Peter Murrell }\end{array}$ & Oct. 1997 \\
\hline $\begin{array}{l}\text { No. 82: Published in: European Economic Review, "Unemployment } \\
\text { Dynamics and the Restructuring of the Slovak Unemployment Benefit } \\
\text { System." Apr., } 1997 .\end{array}$ & $\begin{array}{l}\text { Martina Lubyova and Jan C. van } \\
\text { Ours }\end{array}$ & June 1997 \\
\hline No. 81: Determinants of Unemployment Duration in Russia & Mark C. Foley & Aug. 1997 \\
\hline No. 80: The Many Faces of Information Disclosure & $\begin{array}{l}\text { Arnoud W.A. Boot and Anjan V. } \\
\text { Thakor }\end{array}$ & Oct. 1997 \\
\hline $\begin{array}{l}\text { No. 79: Published in: Journal of Finance, “Foreign Speculators and } \\
\text { Emerging Equity Markets.”v.22, iss. 2, 2000, pp. 565-613 }\end{array}$ & $\begin{array}{l}\text { Geert Bekaert and Campbell R. } \\
\text { Harvey }\end{array}$ & Aug. 1997 \\
\hline $\begin{array}{l}\text { No. 78: The Relationship Between Economic Factors and Equity } \\
\text { Markets in Central Europe }\end{array}$ & $\begin{array}{l}\text { Jan Hanousek and Randall K. } \\
\text { Filer }\end{array}$ & June 1997 \\
\hline $\begin{array}{l}\text { No. } 77 \text { Published in: Economics of Transition, "A Gini Decomposition } \\
\text { Analysis of Inequality in the Czech and Slovak Republics During the } \\
\text { Transition," Vol. 6, No.1, May 1998, pp. 23-46. }\end{array}$ & $\begin{array}{l}\text { Thesia I. Garner and Katherine } \\
\text { Terrell }\end{array}$ & May 1998 \\
\hline $\begin{array}{l}\text { No. 76: China's Emerging Market for Property Rights: Theoretical and } \\
\text { Empirical Perspectives }\end{array}$ & $\begin{array}{l}\text { Gary H. Jefferson and Thomas G. } \\
\text { Rawski }\end{array}$ & June 1997 \\
\hline $\begin{array}{l}\text { No. 75b: Test of Permanent Income Hypothesis on Czech Voucher } \\
\text { Privatization }\end{array}$ & Jan Hanousek and Zdenek Tima & Oct. 1997 \\
\hline $\begin{array}{l}\text { No. 74: Determinants of Performance of Manufacturing Firms in Seven } \\
\text { European Transition Economies }\end{array}$ & $\begin{array}{l}\text { Stijn Claessens, Simeon Djankov, } \\
\text { and Gerhard Pohl }\end{array}$ & Feb. 1997 \\
\hline $\begin{array}{l}\text { No. } 73 \text { Published in: Economics of Transition, "The Restructuring of } \\
\text { Large Firms in Slovak Republic." Vol. 6, No. 1, May 1998, pp. 67-85 }\end{array}$ & $\begin{array}{l}\text { Simeon Djankov and Gerhard } \\
\text { Pohl }\end{array}$ & May 1998 \\
\hline $\begin{array}{l}\text { No. 72: Law, Relationships, and Private Enforcement: Transactional } \\
\text { Strategies of Russian Enterprises }\end{array}$ & $\begin{array}{l}\text { Kathryn Hendley, Peter Murrell, } \\
\text { and Randi Ryterman }\end{array}$ & Nov. 1998 \\
\hline $\begin{array}{l}\text { No. 71: Giving Credit Where Credit Is Due: The Changing Role of } \\
\text { Rural Financial Institutions in China }\end{array}$ & $\begin{array}{l}\text { Albert Park, Loren Brandt, and } \\
\text { John Giles }\end{array}$ & Mar. 1997 \\
\hline $\begin{array}{l}\text { No. 70: Privatization Versus Competition: Changing Enterprise } \\
\text { Behavior in Russia }\end{array}$ & John S. Earle and Saul Estrin & $\begin{array}{l}\text { Spring } \\
1997 \\
\end{array}$ \\
\hline $\begin{array}{l}\text { No. 69: Russian Managers under Storm: Explicit Reality and Implicit } \\
\text { Leadership Theories (A Pilot Exploration) }\end{array}$ & Igor Gurkov & Oct. 1998 \\
\hline $\begin{array}{l}\text { No. 68: The Political Economy of Central-Local Relations in China: } \\
\text { Inflation and Investment Controls During the Reform Era }\end{array}$ & Yasheng Huang & $\begin{array}{l}\text { Spring } \\
1997\end{array}$ \\
\hline $\begin{array}{l}\text { No. 67: Between Two Coordination Failures: Automotive Industrial } \\
\text { Policy in China with a Comparison to Korea }\end{array}$ & Yasheng Huang & $\begin{array}{l}\text { Spring } \\
1997\end{array}$ \\
\hline $\begin{array}{l}\text { No. } 66 \text { Published in: Post-Soviet Geography and Economics, "Red } \\
\text { Executives in Russia’s Transition Economy.” Vol. 27, No. 10, Nov. } \\
\text { 1996, pp. 633-651. }\end{array}$ & Susan J. Linz & Jan. 1997 \\
\hline $\begin{array}{l}\text { No. } 65 \text { Published in: Industrial and Corporate Change, "On the } \\
\text { Sequencing of Privatization in Transition Economies." Vol. 7, No. 1, } \\
1998 .\end{array}$ & $\begin{array}{l}\text { Gautam Ahuja and Sumit K. } \\
\text { Majumdar }\end{array}$ & Apr. 1997 \\
\hline $\begin{array}{l}\text { No. 64: Published in: Journal of Law and Economics, "Foreign } \\
\text { Ownership and Profitability: Property Rights, Control and the } \\
\text { Performance of Firms in Indian Industry" 42(1), Apr. 1999, pp. }\end{array}$ & $\begin{array}{l}\text { Pradeep K. Chhibber and Sumit } \\
\text { K. Majumdar }\end{array}$ & Apr. 1997 \\
\hline
\end{tabular}




\begin{tabular}{|c|c|c|}
\hline No. 63: How Taxing Is Corruption on International Investors? & Shang-Jin Wei & Feb. 1997 \\
\hline $\begin{array}{l}\text { No. 62: What Can We Learn from the Experience of Transitional } \\
\text { Economies with Labour Market Policies? }\end{array}$ & Tito Boeri & 1997 \\
\hline $\begin{array}{l}\text { No. 61: Published in: Accounting Organizations and Society, } \\
\text { "Economic Transition, Strategy and the Evolution of Management } \\
\text { Accounting Practices: The Case of India" 24(5,6), Jul/Aug 1999, pp. } \\
\text { 379-412. }\end{array}$ & $\begin{array}{l}\text { Shannon W. Anderson and } \\
\text { William N. Lanen }\end{array}$ & Apr. 1997 \\
\hline $\begin{array}{l}\text { No. 60a: Enterprise Investment During the Transition: Evidence from } \\
\text { Czech Panel Data }\end{array}$ & Lubomír Lizal and Jan Svejnar & Dec. 1997 \\
\hline $\begin{array}{l}\text { No. 59: Published in: Journal of Law, Economics, and Organization, } \\
\text { "Institutional Environment, Community Government, and Corporate } \\
\text { Governance: Understanding China's Township-Village Enterprises." } \\
\text { 14(1), Apr. 1998, pages 1-23 }\end{array}$ & Jiahua Che and Yingyi Qian & Apr. 1997 \\
\hline No. 58: From the Grabbing Hand to the Helping Hand & Jiahua Che & June 2000 \\
\hline $\begin{array}{l}\text { No. 57: Published in: Brookings Papers on Economic Activity, "The } \\
\text { Unofficial Economy in Transition." 1: } 1998 .\end{array}$ & $\begin{array}{l}\text { Simon Johnson, Daniel } \\
\text { Kaufmann, and Andrei Schleifer }\end{array}$ & June 1997 \\
\hline No. 56: Taxes and Government Incentives: Eastern Europe vs. China & Roger H. Gordon and David D. Li & Apr. 1997 \\
\hline No. 55: Corruption and Reform & Susanto Basu an & June 1996 \\
\hline $\begin{array}{l}\text { No. 54: Decentralization anc } \\
\text { Commitment to State-Owne }\end{array}$ & Loren Brandt and Xiaodong Zhu & June 1997 \\
\hline $\begin{array}{l}\text { No. 53: Published in: The International Journal of Industrial } \\
\text { Organization, "Competitive Shocks and Industrial Structure: The Case } \\
\text { of Polish Manufacturing." Aug., 1999. . }\end{array}$ & $\begin{array}{l}\text { Pankaj Ghemawat and Robert E. } \\
\text { Kennedy }\end{array}$ & May 1997 \\
\hline $\begin{array}{l}\text { No. 52: Published in: The Quarterly Journal of Economics, "Insecure } \\
\text { Property Rights and Government Ownership of Firms." May, } 1998 .\end{array}$ & Jiahua Che and Yingyi Qian & May 1997 \\
\hline No. 51: Incentives, Scale Economies, and Organizational Form & $\begin{array}{l}\text { Eric Maskin, Yingyi Q } \\
\text { Chenggang Xu }\end{array}$ & May 1997 \\
\hline $\begin{array}{l}\text { No. 50: Published in: Post-Soviet-Affairs, "End of the Tunnel? The } \\
\text { Effects of Financial Stabilization in Russia" Apr.-June 1997, pages 105- } \\
33\end{array}$ & $\begin{array}{l}\text { Barry W. Ickes, Peter Murrell, } \\
\text { and Randi Ryterman }\end{array}$ & Mar. 1997 \\
\hline $\begin{array}{l}\text { No. 49: The Evolution of Bank Credit Quality in Transition: Theory and } \\
\text { Evidence from Romania }\end{array}$ & $\begin{array}{l}\text { Enrico C. Perotti and Octavian } \\
\text { Carare }\end{array}$ & Oct. 1996 \\
\hline $\begin{array}{l}\text { No. 48: Where Do the Leaders Trade? Information Revelation and } \\
\text { Interactions Between the Segments of Czech Capital Markets }\end{array}$ & $\begin{array}{l}\text { Jan Hanousek and Libor } \\
\text { Nemecek }\end{array}$ & May 1997 \\
\hline $\begin{array}{l}\text { No. 47: Firms' Heterogeneity in Transition: Evidence from a Polish } \\
\text { Panel Data Set }\end{array}$ & $\begin{array}{l}\text { Irena Grosfeld and Jean-François } \\
\text { Nivet }\end{array}$ & May 1997 \\
\hline No. 46: Strategic Creditor Passivity, Regulation, and Bank Bailouts & Janet Mitchell & May 1997 \\
\hline $\begin{array}{l}\text { No. 45a: Published in: Journal of Public Economics, "Tax Rights in } \\
\text { Transition Economies: A Tragedy of the Commons." } 76,2000 \text {, pp. 369- } \\
397\end{array}$ & Daniel M. Berkowitz and Wei Li & Sept. 1997 \\
\hline $\begin{array}{l}\text { No. 44a: The Information Content of Stock Markets: Why do Emerging } \\
\text { Markets have Synchronous Stock Price Movements? (forthcoming in } \\
\text { the Journal of Financial Economics). }\end{array}$ & $\begin{array}{l}\text { Randall Morck, Bernard Yeung, } \\
\text { and Wayne Yu }\end{array}$ & Feb. 1999 \\
\hline $\begin{array}{l}\text { No. 43: Agency in Project Screening and Termination Decisions: Why } \\
\text { Is Good Money Thrown After Bad? }\end{array}$ & Chong-en Bai and Yijiang Wang & May 1997 \\
\hline $\begin{array}{l}\text { No. 42: Published in: Economics of Transition, "Channels of } \\
\text { Redistribution: Inequality and Poverty in the Russian Transition." Vol. } 7 \\
\text { (2) } 1999 .\end{array}$ & $\begin{array}{l}\text { Simon Commander, Andrei } \\
\text { Tolstopiatenko, and Ruslan } \\
\text { Yemtsov }\end{array}$ & May 1997 \\
\hline $\begin{array}{l}\text { No. 41: Published in: Economics of Transition, "Labour Market } \\
\text { Characteristics and Profitability: Econometric Analysis of Hungarian } \\
\text { Exporting Firms, 1986-1995" 6(1), May 1998, pages 145-62 }\end{array}$ & László Halpern and Gabor Korosi & May 1997 \\
\hline $\begin{array}{l}\text { No. 40: Published in: the Harvard Law Review, "The Tragedy of the } \\
\text { Anticommons: Property in the Transition from Marx to Markets." Jan. } \\
\text { 1998. }\end{array}$ & Michael Heller & Feb. 1997 \\
\hline No. 39: Privatization and Managerial Efficiency & $\begin{array}{l}\text { Olivier Debande and Guido } \\
\text { Friebel }\end{array}$ & May 1997 \\
\hline
\end{tabular}




\begin{tabular}{|c|c|c|}
\hline $\begin{array}{l}\text { No. } 38 \text { Published in: The Quarterly Journal of Economics, } \\
\text { "Disorganization." Vol. 112, No. 4, Nov. 1997, pp. 1091-1126. }\end{array}$ & $\begin{array}{l}\text { Olivier Blanchard and Michael } \\
\text { Kremer }\end{array}$ & Jan. 1997 \\
\hline $\begin{array}{l}\text { No. 37: Published in: Economics of Transition, "Transition and the } \\
\text { Output Fall." 7(1), 1999, pages 1-28. }\end{array}$ & $\begin{array}{l}\text { Gérard Roland and Thierry } \\
\text { Verdier }\end{array}$ & Mar. 1997 \\
\hline $\begin{array}{l}\text { No. 36: Restructuring an Industry During Transition: A Two-Period } \\
\text { Model }\end{array}$ & Richard Ericson & Sept. 1996 \\
\hline No. 34: The East-West Joint Venture: BC Torsion Case Study & $\begin{array}{l}\text { Sonia Ferencikova and Vern } \\
\text { Terpstra }\end{array}$ & Dec. 1998 \\
\hline $\begin{array}{l}\text { No. } 33 \text { Published in: Journal of Comparative Economics, "Quantifying } \\
\text { Price Liberalization in Russia." Vol. 26, No. 4, Dec. 1998, pp. 735-737. }\end{array}$ & $\begin{array}{l}\text { Daniel Berkowitz, David DeJong, } \\
\text { and Steven Husted }\end{array}$ & Dec. 1998 \\
\hline No. 32: What Can North Korea Learn from China's Market Reforms? & John McMillan & Sept. 1996 \\
\hline $\begin{array}{l}\text { No. 31: Published in: China-Economic-Review, "Towards a Model of } \\
\text { China as a Partially Reformed Developing Economy Under a } \\
\text { Semifederalist Government." 9(1), Spring 1998, pages 1-23. }\end{array}$ & Yijiang Wang and Chun Chang & Mar. 1997 \\
\hline $\begin{array}{l}\text { No. 30: Convergence in Output in Transition Economies: Central and } \\
\text { Eastern Europe, 1970-1995 }\end{array}$ & Saul Estrin and Giovanni Urga & Feb. 1997 \\
\hline $\begin{array}{l}\text { No. 29: Published in: Economics of Transition, "Altered Band and } \\
\text { Exchange Volatility." Volume 6, no. 1, 1998, 173-181. }\end{array}$ & Evzen Kocenda & Mar. 1997 \\
\hline $\begin{array}{l}\text { No. 28: Published in: Quarterly Journal of Economics, "Public Versus } \\
\text { Private Ownership of Firms: Evidence from Rural China." Volume 113, } \\
\text { no. 3, Aug. 1998, 773-808. }\end{array}$ & Hehui Jin and Yingyi Qian & Jan. 1997 \\
\hline $\begin{array}{l}\text { No. 27: East-West Joint Ventures in a Transitional Economy: The Case } \\
\text { of Slovakia }\end{array}$ & Sonia Fere & Mar. 1997 \\
\hline $\begin{array}{l}\text { No. 26: Published in Economic Analysis "Behavior of a Slovenian Firm } \\
\text { in Transition" Vol. 1, no. 1, 1998, 57-73. }\end{array}$ & Janez Pra & Feb. 1997 \\
\hline $\begin{array}{l}\text { No. 25: Cultural Encounters and Claims to Expertise in Postcommunist } \\
\text { Capitalism }\end{array}$ & Michael D. Kennedy & Feb. 1997 \\
\hline $\begin{array}{l}\text { No. 24: ZVU a.s.: Investment Funds on the Board of Directors of an } \\
\text { Engineering Giant }\end{array}$ & Tory Wolff & Aug. 1995 \\
\hline $\begin{array}{l}\text { No. 23: The Role of Investment Funds in the Czech Republic (joint } \\
\text { publication with Czech Management Center) }\end{array}$ & Dusan Triska & June 1996 \\
\hline $\begin{array}{l}\text { No. 22: Czech Investment Fund Industry: Development and Behaviour } \\
\text { (joint publication with Czech Management Center) }\end{array}$ & Richard Po & May 1996 \\
\hline $\begin{array}{l}\text { No. 21: Restructuring of Czech Firms: An Example of Gama, a.s. (joint } \\
\text { publication with Czech Management Center) }\end{array}$ & Antonin Bulin & June 1996 \\
\hline $\begin{array}{l}\text { No. 20: YSE Funds: A Story of Czech Investment Funds (joint } \\
\text { publication with Czech Management Center) }\end{array}$ & Michal Otradovec & Nov. 1995 \\
\hline $\begin{array}{l}\text { No. 19: První Investicni a.s., The First Investment Corporation (joint } \\
\text { publication with Czech Management Center) }\end{array}$ & Jaroslav Jirasek & Aug. 1995 \\
\hline $\begin{array}{l}\text { No. 18: PPF a.s., The First Private Investment Fund (joint publication } \\
\text { with Czech Management Center) }\end{array}$ & Michal Otradovec & Nov. 1995 \\
\hline $\begin{array}{l}\text { No. } 17 \text { Published in: Post-Soviet Geography and Economics, "Russia's } \\
\text { Managers in Transition: Pilferers or Paladins?" 37(7) (Sept. 1996), pp. } \\
\text { 397-426. }\end{array}$ & Susan J. Linz and Gary Krueger & Nov. 1996 \\
\hline $\begin{array}{l}\text { No. 16: Banks in Transition-Investment Opportunities in Central } \\
\text { Europe and Russia, Edited Transcript from } 31 \text { May } 1996 \text { Conference in } \\
\text { New York City }\end{array}$ & $\begin{array}{l}\text { With commentary and edited by } \\
\text { Anna Meyendorff }\end{array}$ & Jan. 1997 \\
\hline $\begin{array}{l}\text { No. 15: Marketing in Transitional Economies: Edited Transcript \& } \\
\text { Papers from } 1 \text { Apr. } 1996 \text { Conference in Ann Arbor, Michigan }\end{array}$ & $\begin{array}{l}\text { Compiled by The Davidson } \\
\text { Institute }\end{array}$ & Dec. 1996 \\
\hline $\begin{array}{l}\text { No. 14: Pensions in the Former Soviet Bloc: Problems and Solutions. } \\
\text { Published by Council on Foreign Relations. "The Coming Global } \\
\text { Pension Crisis" New York, } 1997\end{array}$ & Jan Svejnar & Nov. 1996 \\
\hline $\begin{array}{l}\text { No. 13: Enterprise Restructuring and Performance in the Transition. } \\
\text { Forthcoming in Financial Systems in Transition: The Design of } \\
\text { Financial Systems in Central Europe eds. Anna Meyendorff and Anjan } \\
\text { Thakor. }\end{array}$ & $\begin{array}{l}\text { Lubomir Lizal, Miroslav Singer, } \\
\text { and Jan Svejnar }\end{array}$ & Dec. 1996 \\
\hline
\end{tabular}


Davidson Institute Working Papers are available at: www.wdi.bus.umich.edu

\begin{tabular}{|c|c|c|c|}
\hline \multicolumn{2}{|c|}{$\begin{array}{l}\text { No. } 12 \text { Published in: Journal of International Marketing, "Executive } \\
\text { Insights: Marketing Issues and Challenges in Transitional Economies." } \\
\text { Vol. 5, No. 4, 1997, pp. 95-114. Also published in: Marketing Issues in } \\
\text { Transitional Economies ed. Rajeev Batra. }\end{array}$} & Rajeev Batra & Apr. 1997 \\
\hline \multicolumn{2}{|c|}{$\begin{array}{l}\text { No. 11: Worker Trust and System Vulnerability in the Transition from } \\
\text { Socialism to Capitalism }\end{array}$} & Andrew Schotter & Aug. 1996 \\
\hline \multicolumn{2}{|c|}{$\begin{array}{l}\text { No. } 10 \text { Published in: Comparative Economic Studies, "Russian Firms in } \\
\text { Transition: Champions, Challengers, and Chaff." Vol. 39, No.2, } \\
\text { Summer 1997, pp. 1-36. }\end{array}$} & Susan J. Linz & July 1996 \\
\hline \multicolumn{2}{|l|}{$\begin{array}{l}\text { No. 9: Corporate Debt Crisis and Bankruptcy Law During the } \\
\text { Transition: The Case of China }\end{array}$} & David D. Li and Shan Li & Dec. 1995 \\
\hline \multicolumn{2}{|c|}{$\begin{array}{l}\text { No. } 8 \text { Published in: Journal of Comparative Economics, "A Theory of } \\
\text { Ambiguous Property Rights in Transition Economies: The Case of the } \\
\text { Chinese Non-State Sector." Vol. 23, No. 1, Aug. 1996, pp. 1-19. }\end{array}$} & . $\mathrm{Li}$ & June 1996 \\
\hline \multicolumn{2}{|l|}{$\begin{array}{l}\text { No. 7: The Foreign Economic Contract Law of China: Cases and } \\
\text { Analysis }\end{array}$} & $\overline{\text { Dor }}$ & June 1993 \\
\hline \multicolumn{2}{|c|}{$\begin{array}{l}\text { No. 3: Bank Privatization in Hungary and the Magyar Kulkereskedelmi } \\
\text { Bank Transaction }\end{array}$} & $\begin{array}{l}\text { Roger Kormendi and Karen } \\
\text { Schnatterly }\end{array}$ & May 1996 \\
\hline $\begin{array}{l}\text { Replacing No. 1: Journal of Comparative Economics } \\
\text { Symposium on "Bank Privatization in Central Europe and } \\
\text { Russia." Vol. 25, No. 1, Aug. } 1997 .\end{array}$ & \multicolumn{2}{|c|}{$\begin{array}{l}\text { "Bank Privatization in Transitional } \\
\text { Economies," Roger Kormendi and Edward } \\
\text { Snyder. }\end{array}$} & Aug. 1997 \\
\hline $\begin{array}{l}\text { Replacing No. 2: Journal of Comparative Economics } \\
\text { Symposium on "Bank Privatization in Central Europe and } \\
\text { Russia." Vol. 25, No. 1, Aug. } 1997 .\end{array}$ & \multicolumn{2}{|c|}{$\begin{array}{l}\text { "Transactional Structures of Bank } \\
\text { Privatizations in Central Europe and } \\
\text { Russia," Anna Meyendorff and Edward A. } \\
\text { Snyder. }\end{array}$} & Aug. 1997 \\
\hline $\begin{array}{l}\text { Replacing No. 4: Journal of Comparative Economics } \\
\text { Symposium on "Bank Privatization in Central Europe and } \\
\text { Russia." Vol. 25, No. 1, Aug. } 1997 .\end{array}$ & \multicolumn{2}{|c|}{$\begin{array}{l}\text { "Bank Privatization in Poland: The Case of } \\
\text { Bank Slaski," Jeffery Abarbaness and John } \\
\text { Bonin. }\end{array}$} & Aug. 1997 \\
\hline $\begin{array}{l}\text { Replacing No. 5: Journal of Comparative Economics } \\
\text { Symposium on "Bank Privatization in Central Europe and } \\
\text { Russia." Vol. 25, No. 1, Aug. } 1997 .\end{array}$ & \multicolumn{2}{|c|}{$\begin{array}{l}\text { "Bank Privatization in Post-Communist } \\
\text { Russia: The Case of Zhilsotsbank," Jeffery } \\
\text { Abarbanell and Anna Meyendorff } \\
\end{array}$} & Aug. 1997 \\
\hline $\begin{array}{l}\text { Replacing No. 6: Journal of Comparative Economics } \\
\text { Symposium on "Bank Privatization in Central Europe and } \\
\text { Russia." Vol. 25, No. 1, Aug. } 1997 .\end{array}$ & \multicolumn{2}{|c|}{$\begin{array}{l}\text { "The Czech Republic's Commercial Bank: } \\
\text { Komercni Banka," Edward A. Snyder and } \\
\text { Roger C. Kormendi. }\end{array}$} & Aug \\
\hline
\end{tabular}

